\title{
6. SEDIMENTARY FACIES AND DEPOSITIONAL ENVIRONMENT OF THE LOWER CRETACEOUS EAST ANTARCTIC MARGIN: SITES 692 AND 6931
}

\author{
Suzanne B. O’Connell2, 3
}

\begin{abstract}
Lower Cretaceous organic-rich sediments were recovered at Sites 692 and 693 on the eastern Weddell Sea margin during ODP Leg 113, below a major unconformity.

Site 692 ( $2875 \mathrm{~m}$ water depth) is located on a mid-slope bench in Wegener Canyon. Early Cretaceous age (Neocomian, probably Berriasian-Valanginian) sediments extend from 53 to 98 meters below seafloor (mbsf) and are dominated by strongly laminated, organic-rich nannofossil claystone and mudstone with peloids, calcispheres, and radiolarians. Macrofossils (e.g., belemnites and ammonites), thin lenses and nodules containing carbonate-fluorapatite $(<1 \mathrm{~cm}$ diameter), and fluid-escape structures are abundant. Thin beds of devitrified ash and poorly developed graded bedding are present.

Site 693 ( $2360 \mathrm{~m}$ water depth), $30 \mathrm{~km}$ west of Site 692 on the outer canyon rim, yielded Albian age organic-rich claystones and mudstones from 416 to 484 mbsf. Site 693 sediments have organic contents lower than those at Site 692 . Glauconite is common, and three thin limestone beds are present in the upper part of the unit. Well-preserved diatoms, radiolarians, and diatomite layers suggest that the sediments were deposited under conditions of high productivity. Ashclay layers with well-preserved glass shards indicate volcanic activity at the time of deposition.

The sediments at both sites were deposited in an upper bathyal (500-1000 mbsl) marine environment under primarily dysaerobic conditions. At Site 692 the sediment may have experienced periods of anoxia. The sediments at Site 693 record the beginning of oxygenation along the Antarctic margin during the Albian at about the same time as on the Falkland Plateau.
\end{abstract}

\section{INTRODUCTION}

Sites 692 and 693, located on the Dronning Maud Land margin of Antarctica, were the closest to the East Antarctic continent of any site drilled during Leg 113 (Fig. 1). To the surprise and delight of the scientific party, both sites recovered Lower Cretaceous sediments beneath major unconformities. The Early Cretaceous was an interval with common episodes of possible oceanwide stagnation (e.g., Schlanger and Jenkyns, 1976; Meyers and Mitterer, 1986). Sediments of this age from the Antarctic margin provide important new data about the conditions of oceanic stagnation at high southern latitudes.

Site 692 penetrated $45 \mathrm{~m}$ of organic-rich nannofossil claystone and mudstone of Neocomian age below Miocene and Quaternary sediments. These Lower Cretaceous sediments have been dated as Berriasian to Valanginian on the basis of macrofossils, nannofossils, and palynomorphs (Doyle et al., this volume; Mutterlose and Wise, this volume; Mohr, this volume, chapter 29). Site 693 penetrated $77 \mathrm{~m}$ of mid-Cretaceous claystone beneath Oligocene diatom mud. The claystones are early Aptian to early Albian in age (Mutterlose and Wise, this volume; Mohr, this volume, chapter 29; Leckie, this volume). This study, a preliminary investigation of the Lower Cretaceous sediments recovered at Sites 692 and 693, utilizes both shipboard and shore-based data.

\section{METHODS}

The cores were examined and visually described both aboard the JOIDES Resolution and at the ODP East Coast Repository at Lamont-Doherty Geological Observatory. Detailed logs of

\footnotetext{
${ }^{1}$ Barker, P. F., Kennett, J. P., et al., 1990. Proc. ODP, Sci. Results, 113: College Station, TX (Ocean Drilling Program).

2 Ocean Drilling Program, College Station, TX 77840.

3 Present address: Department of Earth and Environmental Sciences, Wesleyan University, Middletown, CT 06457.
}

composition and sedimentary structures were compiled. Samples were selected for X-ray diffraction (XRD), calcium carbonate content, scanning electron microscope (SEM), and thin-section analyses. These samples were selected as representative of the different sedimentary facies and of downcore variations within the same facies. Shipboard XRD and $\mathrm{CaCO}_{3}$ analyses are included in this study.

Shipboard XRD analyses were done on both bulk and clay samples, after removing the carbonate component. For the bulk analysis, samples were ground, wetted, and dropped onto a glass slide and oven dried. For clay analysis, samples were deflocculated using sodium hexametaphosphate solution and homogenized. The clay fraction $(<2 \mu \mathrm{m})$ was separated and washed repeatedly using a centrifuge. The clay residue was then deposited onto glass slides and oven dried. X-ray patterns were run on a Philips ADP $3520 \mathrm{X}$-ray diffractometer with a nickel-filtered $\mathrm{Cu}-\mathrm{K}$ alpha radiation. Three separate $\mathrm{X}$-ray analyses were run on each clay sample, from $2^{\circ}$ to $32^{\circ}$ at a scan speed of $1^{\circ} 2 \theta /$ min, using $\mathrm{Cu}$ radiation, a $\mathrm{Ni}$ filter, and a monochromator. These were (1) on a natural slide, (2) on a slide saturated with ethylene glycol, and (3) on a slide heated to $550^{\circ} \mathrm{C}$ for $1 \mathrm{hr}$.

Shore-based XRD analyses were run only on the bulk samples and without special treatment. These samples were prepared by air drying and crushing. Powder mounts were made by packing the powdered sample into Teflon-impregnated aluminum sample holders. Care was taken to ensure that the sample surface was even and flush with the surface of the sample holder. Diffraction patterns were generated on a Rigaku automated Xray diffractometer driven by an IBM AT computer. Measurements were made using a continuous scan from $3^{\circ}$ to $70^{\circ}$ at $2 \theta$ at a speed of $10^{\circ} 2 \theta / \mathrm{min}$. During measurement, the samples were spun to eliminate biases introduced by sample heterogeneities. The patterns were plotted on a Hewlett-Packard 7475A plotter, and peaks were picked using software by Rigaku.

Additional samples were analyzed for calcium carbonate. The same method was used for both shipboard and shore-based measurements. Samples were freeze dried, crushed, weighed to 


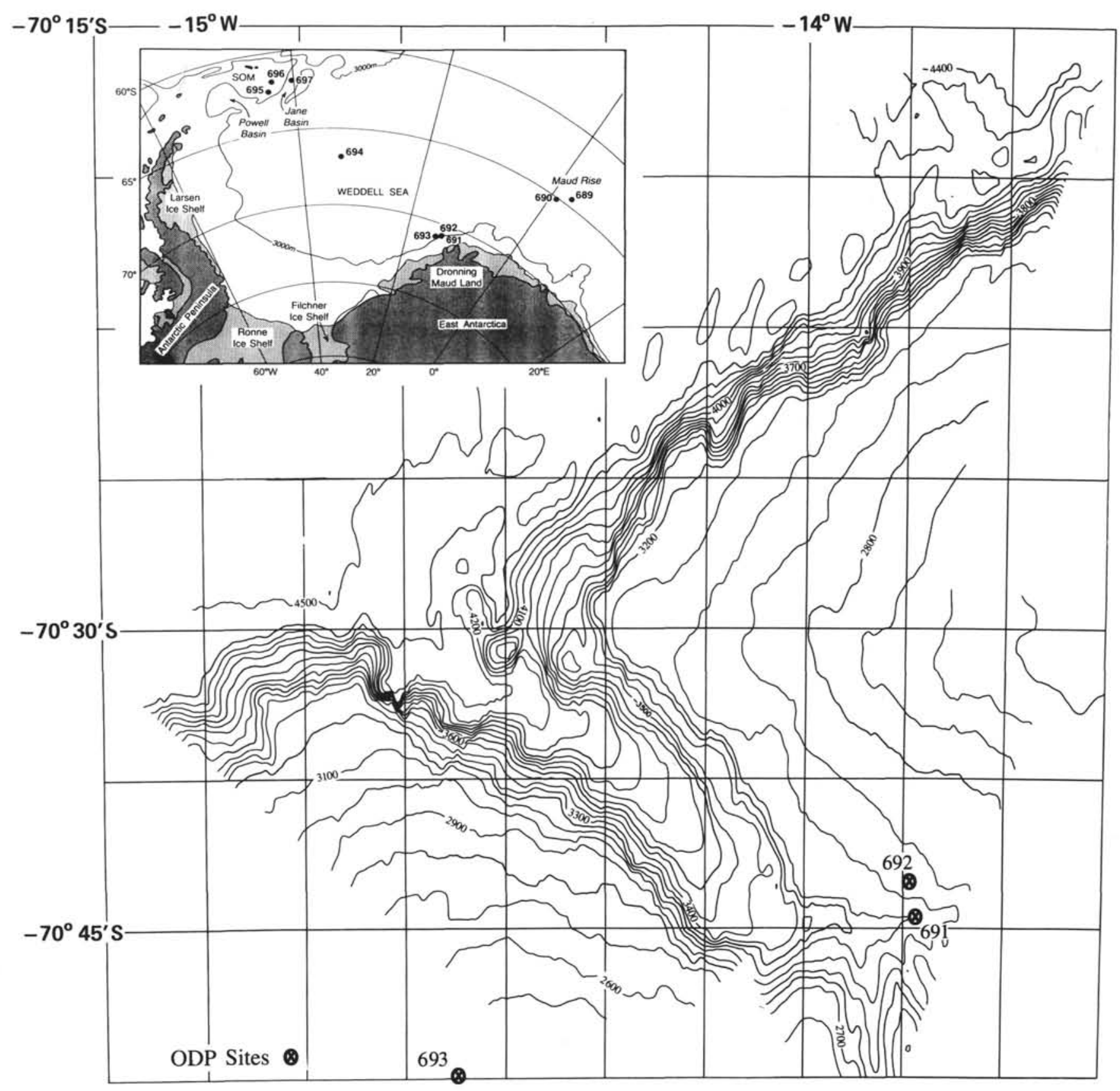

Figure 1. Location of ODP Sites 691-693 in Wegener Canyon. Insert shows location of sites and within the Weddell Sea (from Shipboard Scientific Party, 1988).

the nearest $0.001 \mathrm{~g}$, and placed in a test tube. Total $\mathrm{CaCO}_{3}$ content was determined using a Coulometrics $\mathrm{CO}_{2}$ Coulometer to determine the amount of liberated $\mathrm{CO}_{2}$ (Huffman, 1977). Percent $\mathrm{CaCO}_{3}$ was calculated, assuming all the carbonate to be calcite, using the formula $\% \mathrm{CaCO}_{3}=\% \mathrm{C}_{\text {inorg }} \times 8.334$.

Selected samples were thin-sectioned for light microscope analysis. To do this, sample chips were impregnated prior to mounting and polishing. Some thin sections and freshly fractured rock chips were analyzed with a JEOL JSM 35CF scanning electron microscope (SEM) with a Tracor Northern energydispersive X-ray spectrometer.

\section{SITE 692}

\section{Background and Drilling Conditions}

During Leg 113, one site was planned adjacent to the Antarctic continent to examine the Cenozoic record of Antarctic glaciation and pre-glacial climate in a setting that would be influenced by continental as well as marine information. To do this, a site was selected on the Dronning Maud Land margin of Antarctica. The first site attempted, Site 691 (Fig. 1), could not be drilled because gravel lying near the seafloor prevented the drill string from spudding in. The ship was moved 2 mi north, 
away from the canyon floor. There, after one unsuccessful attempt, Hole 692B was spudded in $2875 \mathrm{~m}$ of water with the rotary core barrel (RCB). Hole 692B, however, was plagued with drilling problems, primarily attributed to sand and gravel in the upper $53 \mathrm{~m}$ which tended to fall downhole as drilling proceeded. Overall recovery in this interval averaged about $14 \%$. The coarse sediment caused hole stability problems, and two wash (W) cores, 113-692B-11W and 113-692B-13W, were taken because the hole had to be redrilled when sediment fell into it. These difficult coring conditions and a desire to attain other (Cenozoic) drilling objectives led to hole abandonment at 98 mbsf.

\section{Hole 692B}

Hole 692B is located on a mid-slope bench in Wegener Canyon off the Antarctic continental margin (Fig. 1). The drillstring penetrated $30 \mathrm{~m}$ of Miocene to Quaternary silty and clayey mud underlain by $23 \mathrm{~m}$ of mixed Tertiary and Mesozoic "gravel," interpreted as canyon fill. Presumed in situ sediment chips from this interval contain Pliocene and upper middle Miocene diatom assemblages, thus dating the onset of canyon formation as no younger than early late Miocene. Lower Cretaceous organicrich claystones and mudstones were encountered between 53 and 98 mbsf, at which depth the hole was terminated.

The Lower Cretaceous (Berriasian-Valanginian) sediments comprise one facies, nannofossil-bearing claystone and mudstone, with varying percentages of clay, mud, nannofossils, and organic matter (Fig. 2). No cyclicity is apparent. The claystone and mudstone consists dominantly of smectite (Shipboard Scientific Party, 1988) with minor amounts of variably preserved calcareous nannofossils, calcispheres, framboidal pyrite, and radiolarians. Quartz and feldspar are present in minor amounts (Tables 1 and 2). Carbonate percentages range from less than $1 \%$ to $33 \%$ (Table 3 ). Porosity ranges from $55.5 \%$ to $48.4 \%$, but with low permeability. Shipboard determinations using index properties (bulk density, porosity, water content, and grain density) suggest that the Lower Cretaceous sediments were previously buried to a depth of $250-300 \mathrm{~m}$, indicating approximately $200 \mathrm{~m}$ of sediment removal. Organic carbon content ranges from $3.6 \%$ to $17.8 \%$, averaging $8.6 \%$. Paleomagnetic data suggest that the sediments were deposited at a paleolatitude of approximately $43^{\circ} \mathrm{S}$ (Shipboard Scientific Party, 1988).

Benthic foraminifer assemblages are widely variable, have a low diversity, and suggest an upper bathyal (500-1000 m) depositional environment, most probably toward the upper part of this depth range. The faunal variability is interpreted (Shipboard Scientific Party, 1988) as resulting from low but varying levels of oxygen in the depositional environment, with less favorable conditions during the deposition of Core 113-692B-7R and the upper parts of Core 113-692B-8R. This interpretation is supported by the high concentration of organic carbon and framboidal pyrite.

Four aspects of these sediments are particularly interesting and useful for interpreting the depositional environment: (1) composition and sedimentary structures, (2) common to abundant carbonate-clay nodules and lenses, (3) rare to common macrofossils, and (4) high organic content.

\section{Composition and Sedimentary Structures}

Thin-section and XRD analyses (Tables 1 and 3) show the matrix to consist dominantly. of clay minerals, with variable amounts of carbonate in the form or nannofossils, calcispheres, and calcite rhombs with twins. In many layers no nannofossils are present, in others they dust the entire surface. Calcispheres, indicative of a stressed environment, vary from $0 \%$ to $20 \%$ of the field of view (magnification $10 \times$ ). They are always circular and commonly occur in layers parallel to the bedding plane.
Also abundant are peloidal-shaped features, with high silica contents. In several areas, particularly within the lenses and nodules, these structures have shapes similar to radiolarians or diatoms, suggesting that they are altered siliceous organisms. Although commonly round, they are more typically observed flattened parallel to the bedding plane, and they may comprise up to $50 \%$ of a field of view (magnification $10 \times$ ).

Less common but also present is organic material, as long, thin particles lying parallel to bedding, and pyrite, occurring as framboidal rhombs and disseminated pieces. Biotite and other accessory minerals are rare. Glauconite, as fresh, green, rounded and sub-angular grains, is observed in only two minor intervals.

Parallel lamination is the dominant sedimentary structure, observable on both a macroscopic (Fig. 3) and a microscopic scale. The laminae are formed by changes in abundance of carbonate particles, alignment of organic material and shell fragments (primarily ribbed bivalves), and minor changes in particle size. Cross lamination, although rare, is observed in a few thin intervals (Fig. 4). In some layers, also rare, weak normal and reverse grading is present, typically defined by changes in the size of carbonate material.

Fluid-escape structures are observed throughout the interval, identified as thin, very dark, commonly sinuous layers with a dominantly vertical trend. Individual structures can be traced for no more than $10 \mathrm{~cm}$ on a cut surface. In thin section, material within the fluidized areas is more fine grained, and some regions contain finely disseminated pyrite which has been remobilized. In other fluidized areas, calcite rhombs appear to be concentrated within or adjacent to fluidized areas.

Fluid-escape structures are most readily identified where they intersect nodules and lenses, which they separate and commonly displace (Fig. 5). Dissolution and fragmentation of the lenses is commonly observed within $0.5 \mathrm{~cm}$ of the nodule along the fluid-escape plane.

Bioturbation structures are difficult to see in this dark material with relatively little color contrast. Nevertheless, they are observed in some intervals throughout the section (Fig. 2), particularly associated with lithologic contacts (e.g., Fig. 6). They are never common and lie within the Savdra et al. (1984) fabric type 2 and 3 or the Droser and Bottjer (1986) ichnofabric index 2 , and rarely 3 .

\section{Lenses and Nodules}

Carbonate-clay concretions are present throughout the cored interval (Fig. 2). They typically occur as (1) nodules and lenses, generally elliptical in cross section and $0.5-2 \mathrm{~cm}$ high and 1-3 $\mathrm{cm}$ long, the longer ones commonly having a boudined appearance; (2) micronodules, smaller ( $20 \mu \mathrm{m}$ and larger) and more abundant; and (3) carbonate-clay layers, less than $1 \mathrm{~cm}$ thick.

Visually the concretions have two different textures and colors. Type I nodules and lenses have a coarser texture and a yellowish-brown color, and they are more likely to be "flattened" parallel to bedding and to have diffuse and rounded edges (e.g., Fig. 7). They are commonly offset and dissected by fluid-escape structures (Fig. 5). Type II nodules and lenses are finer grained, grayer, and less common. They are more likely to be smaller and round, to deflect underlying layers, and to not be offset by fluid-escape structures (Fig. 5). In many nodules, the gray color is present in the center with a browner, more weathered outer rim. The extent of brown vs. gray does not have any systematic variation with location in the section, fluid-escape structures, or nodule size.

Carbonate-clay layers are similar to Type I carbonate-clay nodules and lenses and are more common than nodules between 53.4 and 71.3 mbsf. They are called "layers" if they extend across the cut surface and range in thickness from about $2 \mathrm{~mm}$ 


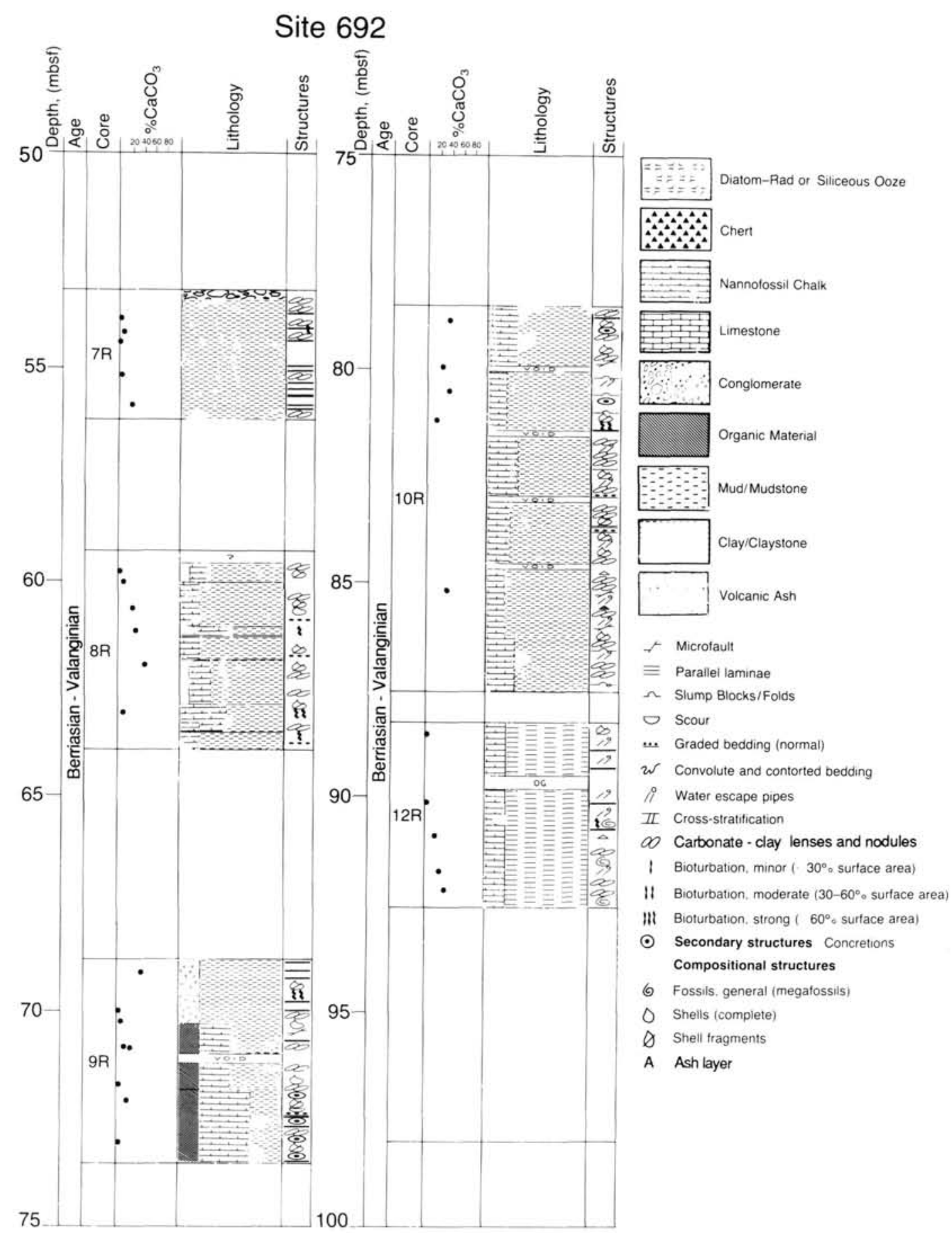

Figure 2. Generalized lithostratigraphy and sedimentary structures of Lower Cretaceous sediments from Site 692, also showing calcium carbonate content. Cores 11 and 13 are not shown because they are wash cores and therefore from an undetermined interval.

to $1 \mathrm{~cm}$. These layers commonly have a boudined appearance. Their similarity to Type I nodules and lenses suggests that they may be the same feature. Based on competence and shape, micronodules are most likely to be Type I nodules. In thin section, they are less competent than adjacent foraminifer tests.

XRD analyses of the Type I nodules (Table 1) indicate that clay minerals, calcite $\left(\mathrm{CaCO}_{3}\right)$, and calcium apatite/calcium fluorapatite $\left[(\mathrm{Ca}, \mathrm{Mg}, \mathrm{Na}, \mathrm{K})_{5}\left(\mathrm{PO}_{4}, \mathrm{CO}_{3}\right)_{3}(\mathrm{~F}, \mathrm{OH})\right]$, are the dominant minerals present in the nodules (Fig. 8A). The abundance of phosphorus is substantiated by the energy-dispersive X-ray spectrometer analysis scan of one of the nodules (Fig. 8B). With the exception of the decrease in organic material and the increase in calcium apatite, the nodules are very similar in composition to the matrix. Radiolarians show slightly better preservation in the nodules.

In thin section, the nodules commonly show variations in mineral abundance, but these are within the compositional range of the matrix. The most dramatic difference is one of color. The nodules do not have a brown stain. If the brown stain is primarily attributed to organic material, then it would be expected that 
Table 1. Hole 692B mineralogy determined from X-ray diffraction patterns. Abundance estimates are based on inweighted area under the highest peak, calculated as relative percent. An X in the calcite column means that calcite was removed prior to analysis. $\mathbf{M}=$ matrix (clay or mud), $\mathbf{N}=$ module.

\begin{tabular}{|c|c|c|c|c|c|c|c|}
\hline $\begin{array}{l}\text { Core, section } \\
\text { top }(\mathrm{cm})\end{array}$ & $\begin{array}{l}\text { Depth } \\
\text { (mbsf) }\end{array}$ & $\frac{\stackrel{g}{J}}{\text { गु }}$ & 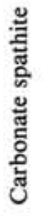 & 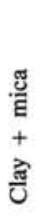 & 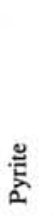 & 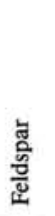 & 苞 \\
\hline \multicolumn{8}{|l|}{ 113-692B- } \\
\hline 7R-1, 44 (M) & 53.64 & $\mathrm{x}$ & - & 53 & 6 & 3 & 40 \\
\hline $7 \mathrm{R}-1,109(\mathrm{~N})$ & 54.29 & $\mathrm{x}$ & 48 & 24 & 7 & 7 & 14 \\
\hline $7 \mathrm{R}-1,120(\mathrm{~N})$ & 54.40 & 6 & 32 & 54 & 3 & 5 & 6 \\
\hline $7 \mathrm{R}-1,120$ (M) & 54.40 & 4 & - & 56 & - & 4 & 37 \\
\hline $7 \mathrm{R}-2,0(\mathrm{M})$ & 54.70 & 5 & - & 52 & 1 & 2 & 45 \\
\hline $7 \mathrm{R}-2,26(\mathrm{M}-\mathrm{N})$ & 54.96 & $\mathrm{x}$ & 21 & 45 & 12 & 5 & 17 \\
\hline $8 \mathrm{R}-1,76(\mathrm{M})$ & 60.06 & 2 & - & 90 & 2 & - & 6 \\
\hline $8 \mathrm{R}-3,110(\mathrm{M})$ & 63.40 & 32 & - & 38 & - & - & 30 \\
\hline $8 \mathrm{R}-3,110(\mathrm{M})$ & 63.40 & 14 & - & 56 & 1 & - & 28 \\
\hline $9 \mathrm{R}-1,80(\mathrm{M})$ & 69.60 & - & - & 32 & 12 & 12 & 43 \\
\hline $9 \mathrm{R}-1,95(\mathrm{M})$ & 69.75 & $\mathrm{X}$ & & & & & \\
\hline $9 \mathrm{R}-3,45(\mathrm{~N})$ & 72.25 & 48 & - & 24 & 1 & - & 27 \\
\hline $10 \mathrm{R}-3,121(\mathrm{~N})$ & 82.71 & 25 & 30 & 37 & 3 & - & 5 \\
\hline $10 \mathrm{R}-3,121(\mathrm{M})$ & 82.75 & 32 & - & 43 & 3 & - & 22 \\
\hline $10 \mathrm{R}-3,129(\mathrm{~N})$ & 82.83 & 56 & 26 & 12 & 3 & 1 & 3 \\
\hline $12 \mathrm{R}-1,119$ (M) & 89.39 & 6 & 6 & 42 & 4 & - & 42 \\
\hline $12 \mathrm{R}-3,60(\mathrm{~N})$ & 91.80 & 18 & 45 & 26 & 2 & 5 & 4 \\
\hline
\end{tabular}

Table 2. Calcium carbonate percentages at Hole 692B from shipboard and shore-based analyses for Hole 692B. M $=$ matrix (clay or mud), $\mathbf{N}=$ nodule.

\begin{tabular}{|c|c|c|}
\hline $\begin{array}{l}\text { Core, section, } \\
\text { interval }(\mathrm{cm})\end{array}$ & $\begin{array}{l}\text { Depth } \\
\text { (mbsf) }\end{array}$ & $\underset{(\%)}{\mathrm{CaCO}_{3}}$ \\
\hline \multicolumn{3}{|l|}{ 113-692B- } \\
\hline $7 \mathrm{R}-1,47-48(\mathrm{M})$ & 53.67 & 3.75 \\
\hline 7R-1, 93-94 (M) & 54.13 & 8.42 \\
\hline $7 \mathrm{R}-1,115-116(\mathrm{M})$ & 54.35 & 0.83 \\
\hline $7 \mathrm{R}-2,42-43(\mathrm{M})$ & 55.12 & 3.75 \\
\hline $7 \mathrm{R}-2,112-113(\mathrm{M})$ & 55.82 & 22.60 \\
\hline $8 \mathrm{R}-1,46-47(\mathrm{M})$ & 59.76 & 3.42 \\
\hline $8 \mathrm{R}-1,71-72(\mathrm{M})$ & 60.01 & 8.92 \\
\hline $8 \mathrm{R}-1,131-132(\mathrm{M})$ & 60.61 & 25.10 \\
\hline $8 \mathrm{R}-2,30-31(\mathrm{~N})$ & 61.10 & 32.11 \\
\hline $8 \mathrm{R}-2,116-117(\mathrm{M})$ & 61.96 & 41.12 \\
\hline $8 \mathrm{R}-3,126-127(\mathrm{M})$ & 63.56 & 12.43 \\
\hline $9 \mathrm{R}-1,32-33(\mathrm{M})$ & 69.12 & 41.87 \\
\hline $9 \mathrm{R}-1,118-119(\mathrm{M})$ & 69.98 & 3.09 \\
\hline $9 \mathrm{R}-1,143-146(\mathrm{M})$ & 70.23 & 5.67 \\
\hline $9 \mathrm{R}-2,52-53(\mathrm{M})$ & 70.82 & 15.68 \\
\hline $9 \mathrm{R}-2,55-56(\mathrm{~N})$ & 70.85 & 22.19 \\
\hline $9 \mathrm{R}-2,101-104(\mathrm{~N})$ & 71.31 & 25.05 \\
\hline 9R-2, 143-144 (M) & 71.73 & 3.42 \\
\hline $9 \mathrm{R}-3,6-8(\mathrm{~N})$ & 71.86 & 32.61 \\
\hline $9 \mathrm{R}-3,35-36(\mathrm{M})$ & 72.15 & 22.69 \\
\hline $9 \mathrm{R}-3,122-123(\mathrm{M})$ & 73.02 & 4.42 \\
\hline $10 \mathrm{R}-1,42-43(\mathrm{M})$ & 78.92 & 35.11 \\
\hline $10 \mathrm{R}-1,116-117(\mathrm{M})$ & 79.66 & 23.35 \\
\hline $10 \mathrm{R}-2,51-52(\mathrm{M})$ & 80.51 & 32.78 \\
\hline $10 \mathrm{R}-2,113-114(\mathrm{M})$ & 81.13 & 13.93 \\
\hline 10R-5, 128-129 (M) & 85.78 & 32.03 \\
\hline $11 \mathrm{R}-1,113(\mathrm{~N})$ & - & 22.50 \\
\hline $12 \mathrm{R}-1,28-29(\mathrm{M})$ & 88.48 & 2.67 \\
\hline $12 \mathrm{R}-1,119-121(\mathrm{~N})$ & 89.39 & 23.26 \\
\hline $12 \mathrm{R}-2,36-37(\mathrm{M})$ & 90.06 & 3.00 \\
\hline $12 \mathrm{R}-2,110-111(\mathrm{M})$ & 90.80 & 18.85 \\
\hline $12 \mathrm{R}-3,44-45(\mathrm{M})$ & 91.64 & 23.27 \\
\hline $12 \mathrm{R}-3,99-100(\mathrm{M})$ & 92.19 & 31.44 \\
\hline
\end{tabular}

relatively little organic material is present in the nodules. This difference is confirmed by Rock-Eval analyses (Shipboard Scientific Party, 1988). The nodules also contain up to $50 \%$ carbonate apatite (Table 1). Minerals within the nodules lack the well-formed hexagonal prismatic shape characteristic of apatite, and therefore the form is probably similar to dahllite or collophane.

Although apatite has been successfully formed in several different laboratory experiments (Ames, 1959), there is no consensus about how it forms in nature, possibly indicating formation by more than one method. In general, apatite is found on the outer shelf (30-500 $\mathrm{m}$ water depth, with water depth not exceeding $1000 \mathrm{~m}$ ), in organic-rich (primarily upwelling) warm-climate areas between $40^{\circ} \mathrm{N}$ and $\mathrm{S}$, and in slightly alkaline environments. Apatite formation is inhibited by $\mathrm{Mg}$ ions (Martens and Harriss, 1970), and $\mathrm{Mg}$, if present at all, exists in very low quantities. Phosphate commonly occurs as nodules, although the nodules described in the literature do not resemble those recovered at this site. One suggestion for apatite formation is through concentration by carbonate dissolution, since apatite is so much less soluble than calcite. This may have happened in some nodules, for example those offset by the fluid-escape structures.

In some sediments, for example the Pliocene and Albian-Cenomanian of the North Atlantic, carbonate nodules selectively develop as a burrow-fill replacement (von Rad and Botz, 1983). Burrow filling may have contributed to the nucleation of the nodules in these samples. Organic material would be removed by burrowing organisms. The nodules have a low organic content relative to the matrix, so burrow-fill replacement may have contributed to nodule formation.

Another common carbonate mineral in organic-rich sediments is siderite, which precipitates during "early" diagenesis when pore waters have slightly negative Eh (approximately $0.2-$ $0.4 \mathrm{~V})$, intermediate $\mathrm{pH}(6-8)$, abundant $\mathrm{Fe}^{++}$, high $\mathrm{pCO}^{2}$, and very low S-concentrations (Garrels and Christ, 1965; Berner, 1971). It is more common in Paleozoic than Mesozoic or Cenozoic rocks (van Moort, 1973). In other marine occurrences (e.g., von Rad and Botz, 1983), siderite is associated with magnesium and manganese carbonate minerals; dolomite, ankerite, and rhodochrosite. Both XRD and energy-dispersive SEM analysis failed to identify any siderite or other carbonate minerals in these Lower Cretaceous sediments.

\section{Macrofossils}

Macrofossils, preserved as original shell fragments and imprints, are common (Fig. 9), and consist of mollusks and other ribbed bivalves, ammonites, serpulid worm tubes, and belemnites. Although they commonly lie in the bedding plane (Fig. 9A) with the concave side facing upward, they also lie at an angle to the bedding plane with the ribs facing upward (Fig. 9B; see Doyle et al., this volume).

\section{Organic Carbon Content}

Shipboard analyses show the total organic carbon averages $8.6 \%$, ranging between $1.85 \%$ (nodule) and $18.41 \%$. Lipid matter is dominated by planktonic contributions. The excellent preservation requires anoxic bottom waters. The one carbonate-clay nodule analyzed had a lower Hydrogen Index and a higher Oxygen Index than the clayey matrix, indicating a more continental and oxidized signature than the host sediment (Shipboard Scientific Party, 1988; Thompson and Dow, this volume; Kvenvolden et al., this volume). This difference could support an allochthonous origin for the nodules, rather than in situ precipitation.

\section{Depositional Environment}

The Lower Cretaceous sediments at Site 692 were deposited under dysaerobic but at times aerobic and $\mathrm{CO}_{2}$-rich conditions at the sediment-water interface. Changes in abundance of cal- 
Table 3. Thin section descriptions and mineralogy for Hole 692B. Mineral percents are based on visual percentages (Terry and Chilingarian, 1955). Size designations are: Major (M) $65 \%-35 \%$, Common (C), $35 \%-5 \%$, and Trace (T) $<5 \%$.

\begin{tabular}{|c|c|c|c|c|c|c|c|c|c|c|c|c|c|c|c|}
\hline $\begin{array}{l}\text { Core, section } \\
\text { top }(\mathrm{cm})\end{array}$ & $\begin{array}{l}\text { Depth } \\
\text { (mbsf) }\end{array}$ & 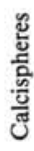 & 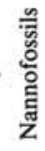 & 总 & 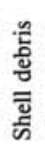 & 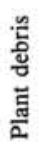 & $\frac{0}{0}$ & & 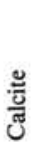 & 즘 & 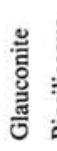 & 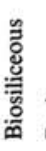 & 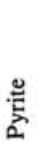 & & Comments \\
\hline \multicolumn{16}{|l|}{ 113-692B- } \\
\hline $7 \mathrm{R}-2,0$ & 54.70 & - & $T$ & - & $\mathrm{T}$ & C & $\mathrm{T}$ & - & $T$ & M & $-\mathrm{c}$ & C & C & (M) & \\
\hline $8 \mathrm{R}-3,21$ & 62.51 & $\bar{c}$ & $\begin{array}{l}\mathrm{T} \\
\mathrm{C}\end{array}$ & $\overline{-}$ & $\begin{array}{l}\mathrm{T} \\
\mathrm{T}\end{array}$ & $\begin{array}{l}\mathrm{C} \\
\mathrm{C}\end{array}$ & $\begin{array}{l}\mathrm{T} \\
\mathrm{T}\end{array}$ & - & $\begin{array}{l}\mathrm{T} \\
\mathrm{C}\end{array}$ & $\begin{array}{l}\mathrm{M} \\
\mathrm{C}\end{array}$ & - & $\begin{array}{l}\mathrm{C} \\
\mathrm{T}\end{array}$ & $\begin{array}{l}\mathrm{C} \\
\mathrm{C}\end{array}$ & $\begin{array}{l}\text { (M) } \\
\text { (N) }\end{array}$ & $\begin{array}{l}\text { Calcite in matrix is on } \\
\text { rhombs. }\end{array}$ \\
\hline $8 \mathrm{R}-3,110$ & 63.40 & $\mathrm{~T}$ & $\mathrm{M}$ & $T$ & $\mathrm{~T}$ & $\mathrm{C}$ & - & - & $T$ & M & - & - & C & (M) & $\begin{array}{l}\text { Very fine grained } \\
\text { sediment. }\end{array}$ \\
\hline $9 \mathrm{R}-1,95$ & 69.75 & $\mathrm{~T}$ & $\mathrm{C}$ & $\mathrm{T}$ & $\mathrm{T}$ & C & C & - & $\mathrm{T}$ & M & - & - & C & (M) & $\begin{array}{l}\text { Strong foliation espe- } \\
\text { cially in peloids. }\end{array}$ \\
\hline $9 \mathrm{R}-2,101$ & 71.31 & $\begin{array}{l}\mathrm{C} \\
\mathrm{T}\end{array}$ & $\begin{array}{l}\mathrm{M} \\
\mathrm{M}\end{array}$ & $\bar{T}$ & $\begin{array}{l}\mathrm{T} \\
\mathrm{T}\end{array}$ & C & $\begin{array}{l}\mathrm{C} \\
\mathrm{M}\end{array}$ & 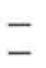 & $\begin{array}{l}\mathrm{C} \\
\mathrm{C}\end{array}$ & C & $\frac{T}{-}$ & $\begin{array}{l}\mathrm{T} \\
\mathrm{C}\end{array}$ & $\begin{array}{l}\mathrm{C} \\
\mathrm{T}\end{array}$ & $\begin{array}{l}\text { (M) } \\
\text { (N) }\end{array}$ & \\
\hline $9 \mathrm{R}-3,06$ & 71.86 & $\begin{array}{l}\mathrm{C} \\
\mathrm{T}\end{array}$ & $\overline{-}$ & $\begin{array}{l}\mathrm{T} \\
\mathrm{T}\end{array}$ & $\frac{T}{-}$ & $\underline{c}$ & $\begin{array}{l}\mathrm{C} \\
\mathrm{C}\end{array}$ & $\bar{T}$ & $\begin{array}{l}\mathrm{C} \\
\mathrm{M}\end{array}$ & $\begin{array}{l}\mathrm{C} \\
\mathrm{C}\end{array}$ & - & $\begin{array}{l}\mathrm{T} \\
\mathrm{C}\end{array}$ & $\begin{array}{l}\mathrm{C} \\
\mathrm{T}\end{array}$ & & \\
\hline $10 \mathrm{R}-2,0$ & 80.00 & C & - & $\mathrm{T}$ & $T$ & $\mathrm{C}$ & $\mathrm{C}$ & - & C & M & - & - & C & (M) & $\begin{array}{l}\text { Many of fluid-escape } \\
\text { structures. }\end{array}$ \\
\hline $10 \mathrm{R}-5,83$ & 85.33 & $\begin{array}{l}\mathrm{C} \\
\mathrm{T}\end{array}$ & $\begin{array}{l}\mathrm{C} \\
\mathrm{C}\end{array}$ & $\overline{-}$ & $\frac{T}{-}$ & $\begin{array}{l}\mathrm{C} \\
\mathrm{T}\end{array}$ & $\begin{array}{l}\mathrm{T} \\
\mathrm{C}\end{array}$ & & & $\begin{array}{l}\mathrm{M} \\
\mathrm{C}\end{array}$ & $=-$ & - & $\begin{array}{l}\mathrm{C} \\
\mathrm{T}\end{array}$ & $\begin{array}{l}\text { (M) } \\
(\mathrm{N})\end{array}$ & $\begin{array}{l}\text { Calcite rhombs and } \\
\text { pyrite in center of } \\
\text { calcispheres. } \\
\text { Amount of plant } \\
\text { debris in nodule } \\
\text { increases toward } \\
\text { outer edge. }\end{array}$ \\
\hline $10 \mathrm{R}-6,0$ & 86.00 & $\begin{array}{l}\mathrm{C} \\
\mathrm{C}\end{array}$ & $\begin{array}{l}\mathrm{C} \\
\mathrm{C}\end{array}$ & $\underline{T}$ & $\frac{T}{-}$ & $\underline{c}$ & $\begin{array}{l}\mathrm{C} \\
\mathrm{C}\end{array}$ & - & $\begin{array}{l}\mathrm{C} \\
\mathrm{C}\end{array}$ & $\begin{array}{l}\mathrm{M} \\
\mathrm{C}\end{array}$ & - & $\begin{array}{l}\mathrm{T} \\
\mathrm{C}\end{array}$ & $\begin{array}{l}\mathrm{C} \\
\mathrm{C}\end{array}$ & $\begin{array}{l}\text { (M) } \\
(\mathrm{N})\end{array}$ & \\
\hline $12 \mathrm{R}-1,119$ & 89.39 & $\begin{array}{l}\mathrm{T} \\
\mathrm{T}\end{array}$ & $\begin{array}{l}\mathrm{T} \\
\mathrm{T}\end{array}$ & $\underline{T}$ & $\frac{T}{-}$ & $\underline{\mathrm{C}}$ & $\begin{array}{l}\mathrm{C} \\
\mathrm{M}\end{array}$ & & $\begin{array}{l}\mathrm{C} \\
\mathrm{C}\end{array}$ & $\begin{array}{l}\mathrm{M} \\
\mathrm{C}\end{array}$ & - & $\begin{array}{l}\mathrm{T} \\
\mathrm{C}\end{array}$ & $\begin{array}{l}\mathrm{C} \\
\mathrm{C}\end{array}$ & $\begin{array}{l}\text { (M) } \\
(\mathrm{N})\end{array}$ & $\begin{array}{l}\text { Foraminifers have pyrite } \\
\text { centers }(\mathrm{M}) \text {. Calcite } \\
\text { is twinned }(\mathrm{N}) \text {. } \\
\text { Quartz and carbon- } \\
\text { ate replacing } \\
\text { radiolarians and } \\
\text { diatoms. }\end{array}$ \\
\hline
\end{tabular}

careous nannofossils on the millimeter scale suggest common changes in productivity/preservation or influx of terrigenous material. The lack of land-derived material, both siliciclastic and organic, and the only minimal evidence for mass-wasting, indicate a quiescent environment removed from the continent. Yet, the upper bathyal depth and the presence of smectite and relatively unbroken macrofossils suggest an outer continental shelf/upper slope environment. In the outer shelf/upper slope, a larger terrigenous component might be expected. Possibly, if sedimentation rates were very high, as suggested by the fluid-escape structures, these sediments may have been deposited over a short period of time during which terrigenous input was deflected by submarine (deltaic?) channels.

Alternatively, another depositional environment that could fulfill these requirements is a relatively shallow silled basin or series of basins. Existing seismic data (ODP Data Bank) do not show such basins, unless the sills and basins are too small to be resolved seismically or they lie between the continent and Site 692. As the southern continent was breaking up during this time, it is possible that small sills capable of impounding terrigenous sediments existed. Cretaceous east-west-trending silled basins are credited with providing the depositional environment in an area of shelf upwelling for the phosphorite deposits in Lebanon (Flexer, 1971) and the Great Syrian Desert (Kemper and Zimmerle, 1983). Phosphate precipitation, in general, is thought to occur in regions of fluctuating redox conditions like those associated with oxygen minimum layers or alternating anoxic-suboxic zones (Arthur and Jenkyns, 1981).

High organic contents and carbonate-apatite nodules are commonly associated with upwelling areas (e.g., Kazakov, 1937; Diester-Haass, 1978; Burnett, 1980; Krissek and Scheidegger, 1983). Sediments deposited in these upwelling areas are associated with high biogenic opal, abundant fish debris, low planktonic/benthic ratios and often with cool-water foraminifers, as well as high amounts of organic matter. The Lower Cretaceous sediments at Site 692 do not meet all of these criteria. Siliceous microfossils rarely exceed $20 \%$, and foraminifers are rare, although benthics are more common than planktonics. In contrast, calcareous nannofossils are common to abundant in some of the Lower Cretaceous intervals (Shipboard Scientific Party, 1988). In the organic-rich sediments of the Santa Barbara Basin, calcium carbonate contents range between $6 \%$ and $14 \%$ (Dunbar, 1983). In the organic-rich sediments of the Peru continental margin, calcium carbonate contents are highly variable, ranging from $1 \%$ to almost $90 \%$ (Reimers and Suess, 1983). In general, the higher carbonate contents off Peru are associated with coarser grained sediments and with lower organic carbon contents. This is attributed to winnowing and scouring of the non-calcium carbonate component in areas of higher bottomcurrent activity. 


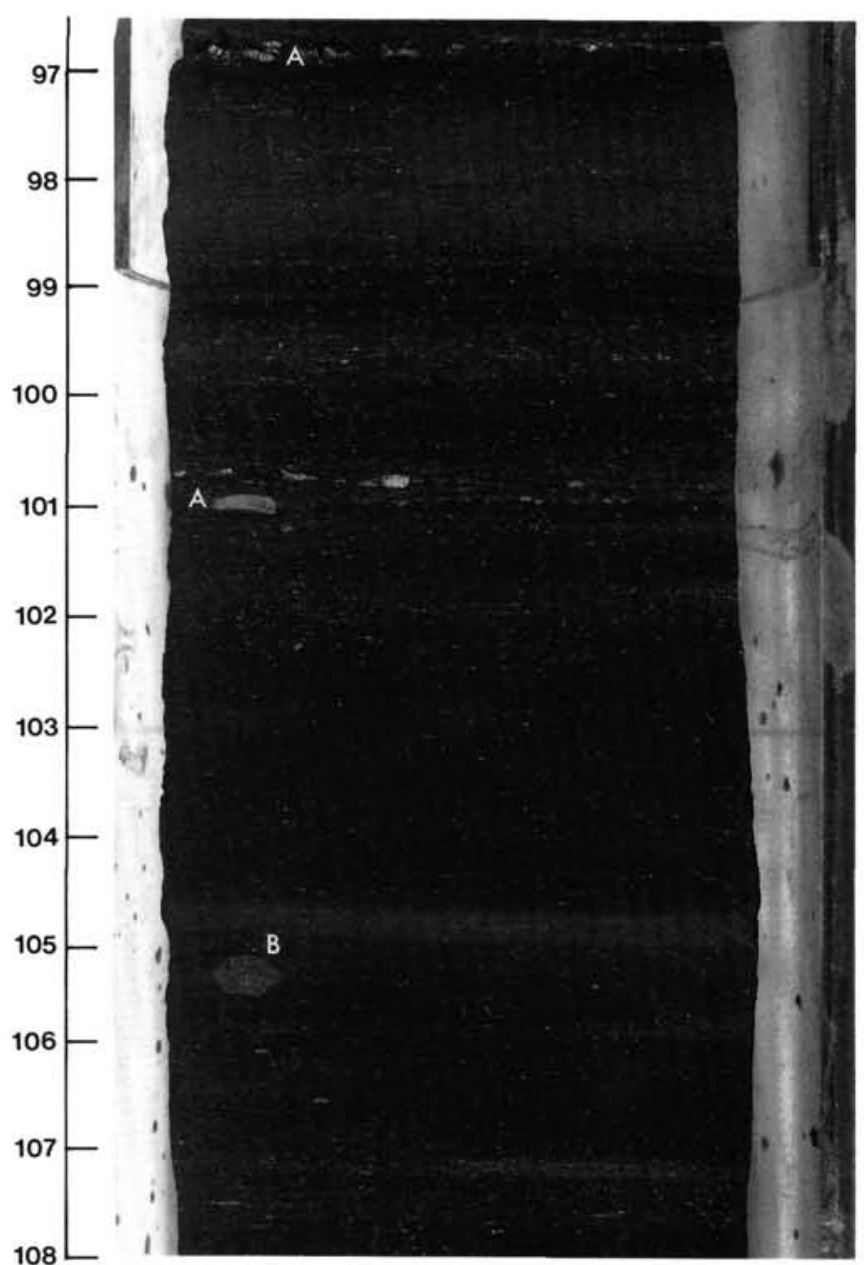

Figure 3. Laminated nannofossil-bearing claystone (Interval 113-692B$8 \mathrm{R}-1,96.5-108 \mathrm{~cm}$ ). Laminations are defined by the abundance of carbonate particles (lighter layers) and finely disseminated organic matter. Also shown are shell fragments (A) and a carbonate-clay nodule (B).

Arguments have also been proposed for phosphorite genesis in non-upwelling areas (O'Brien and Veeh, 1983), and different types of phosphorite deposits under different upwelling conditions (McKelvey, 1967). In the McKelvey model, phosphorites associated with chert and black shales are typically associated with divergence in eastern boundary currents. In contrast, those formed beneath the warmer waters of western boundary currents consist of phosphatic limestones and sandstones.

At least three possible examples of "non-upwelling" phosphorites are recognized: (1) the Precambrian phosphorites of Udaipur and Jhubua in India, which are associated with stromatolites (Banerjee et al., 1980), (2) the Tertiary phosphorite deposits of the southeastern United States coastal plain, thought to be estuarine in origin (Pevear, 1966), and (3) the upper Pleistocene to Holocene phosphatic nodules from the East Australian continental margin. These non-upwelling deposits however, are associated with lower organic carbon contents in the sediments. The $8.6 \%$ average organic content at Site 692 is high even for upwelling areas. Similarly, upwelling areas where nannofossils are present are areas of lower fertility such as the Central Pacific and Atlantic gyres (Schrader and Schuette, 1981; Monteiro et al., 1983).

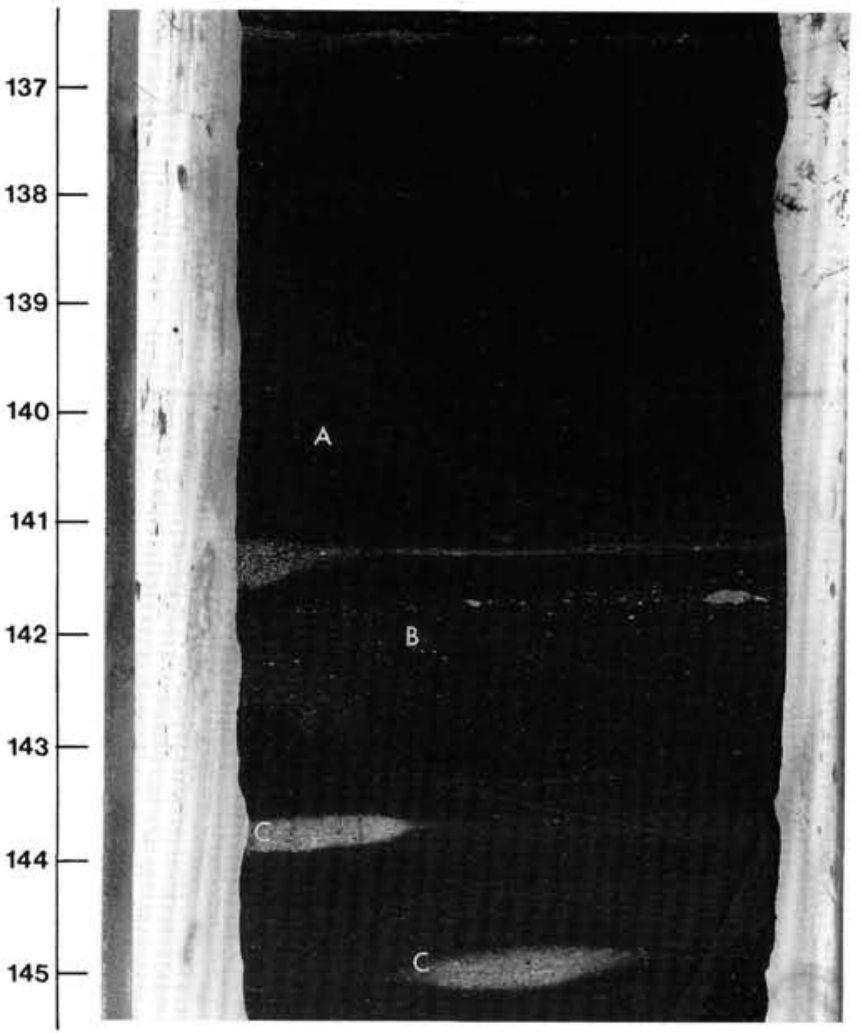

Figure 4. Cross-lamination (A) between parallel lamination (Interval 113-692B-7R-2, 136.5-145.5 cm). Poorly developed reverse grading (B) is shown between 141.5 and $142.5 \mathrm{~cm}$. Carbonate-clay concretions are present at the base of this interval (C).

\section{SITE 693}

\section{Background and Drilling Conditions}

Site 693 is located on a mid-slope bench on the Weddell Sea margin of East Antarctica, $10 \mathrm{~km}$ southwest of the rim of Wegener Canyon and $30 \mathrm{~km}$ west-southwest of Sites 691 and 692 (Fig. 1). Like Sites 691 and 692, Site 693 was drilled to recover a thicker, more complete section to examine the Cenozoic cooling and glaciation of the Antarctic continent. Two holes were drilled. The first, in $2359 \mathrm{~m}$ of water, was cored with the RCB and penetrated $484 \mathrm{~m}$ of seafloor and recovered Lower Cretaceous sediments in the lower section. The second hole, cored with the extended core barrel (XCB), penetrated $403 \mathrm{~m}$ of seafloor. It was terminated immediately below the Cretaceous/Oligocene boundary because the XCB cutter had been worn or broken off and was left in the hole.

\section{Hole 693A}

Three sedimentary facies are recognized in the Lower Cretaceous (lower Aptian to lower Albian) sediments at Site 693, between 397 and 494 mbsf (Fig. 10). In order of increasing abundance the facies are clay-bearing radiolarian diatomite and chert; limestone; and silty mudstone with minor occurrences of clayey and sandy mudstone.

Clay-bearing radiolarian diatomite was recovered only in Core 113-693A-44R. The biosiliceous component decreases downcore in the $75 \mathrm{~cm}$ of recovered sediment. Bioturbation structures are extensive (Fig. 11), and the diatomite is olive gray (5Y 4/2) to dark olive gray (5Y 3/2) in color. Chert is present in Cores 113- 


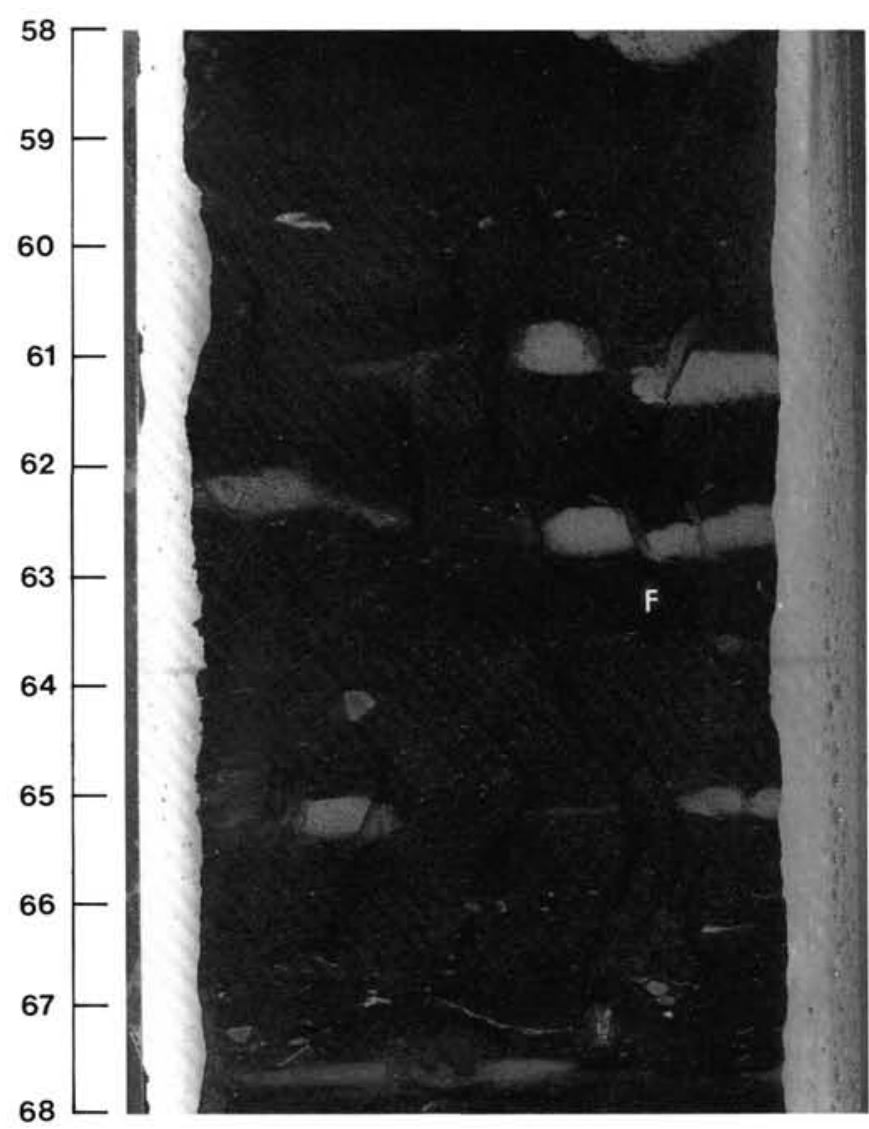

Figure 5. Fluid-escape structures $(\mathrm{F})$ are most easily observed where they offset carbonate concretions (Interval 113-692B-10R-4, 58-68 cm).

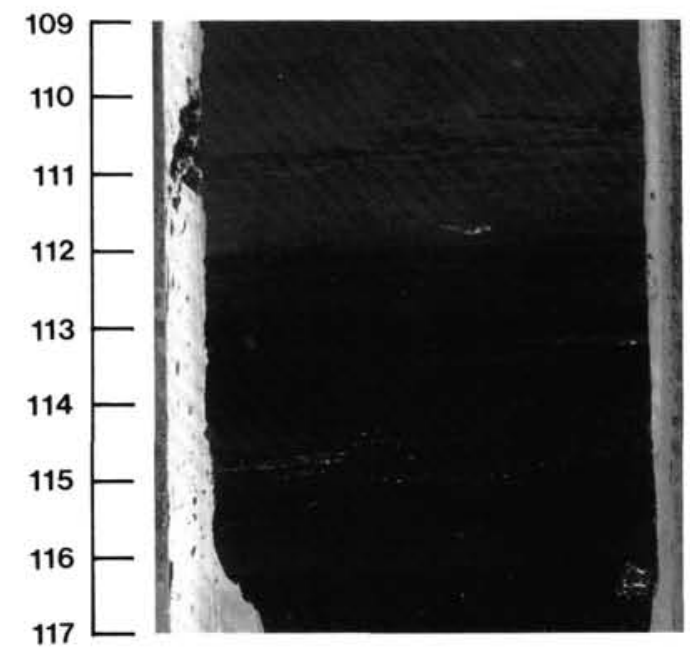

Figure 6. Bioturbated interval, visible because of the minor color differences, although the color contact shows no evidence of bioturbation (Interval 113-692B-8R-3, 109-117 cm). The extent of bioturbation would place this interval in ichnofabric index 2 (Droser and Bottjer, 1986). Shell fragments are present and at $116 \mathrm{~cm}$.

693A-44R through $113-693 \mathrm{~A}-46 \mathrm{R}$ as black to dark gray angular fragments and pieces up to $6 \mathrm{~cm}$ in diameter.

Limestone occurs as light to dark gray ( $5 \mathrm{Y} 5 / 1$ to $5 \mathrm{Y} 4 / 1$ ) layers, 5 to $40 \mathrm{~cm}$ thick, throughout the Lower Cretaceous strata. The limestone is recrystallized, dominantly calcite, with variable

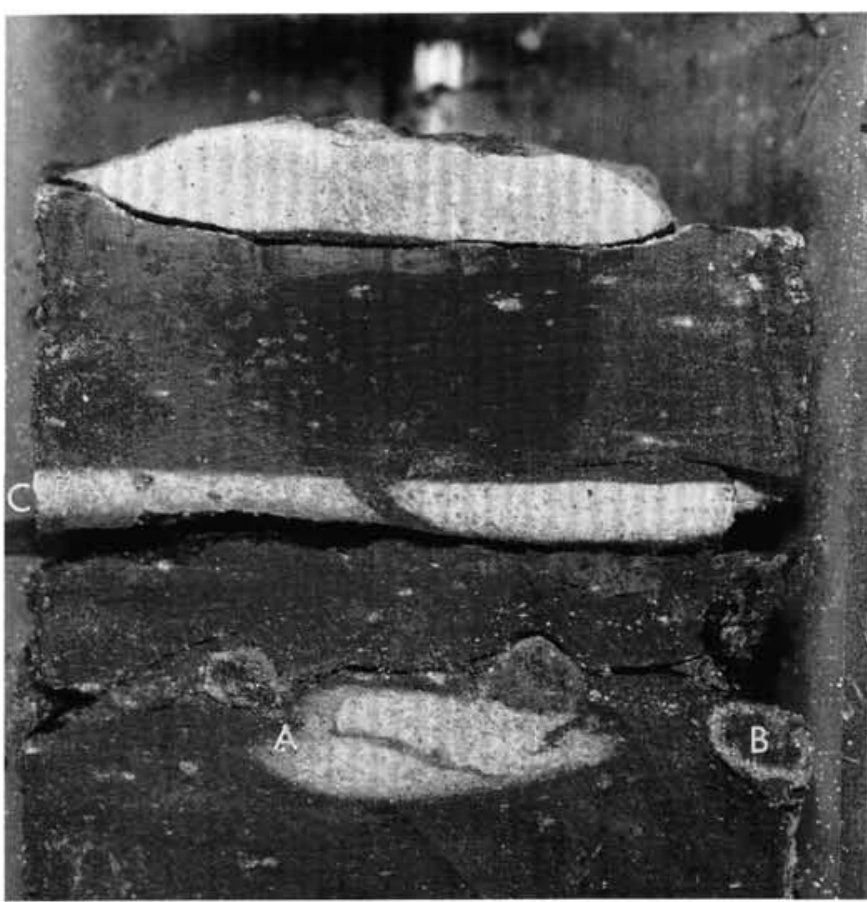

Figure 7. Type I nodule (A), Type II nodule (B) and layer (C). (Interval 113-692B-10R-4, 86-92 cm.

grain sizes. Accessory components include quartz, glauconite, mica, opaques, and radiolarians. Contacts between the limestone and the adjacent sediment in the recovered core are abrupt. In Core 113-693A-48R, the basal limestone is rimmed with a 1-cm-thick layer of pyrite (Fig. 12).

The dominant facies, silty mudstone with minor clayey and sandy mudstone, is very dark in color and composed primarily of terrigenous sediments (Tables 4 and 5). Clay (primarily smectite) is the most abundant mineral, but opaque minerals, volcanic glass (mostly altered), and quartz are common. Minor constituents include calcite, feldspar, mica (commonly chloritized), and biotite. In addition, glauconite is commonly present, and in some layers it is the dominant mineral.

Volcanic glass is most common as microspherules, now altered to clay. Rounded "quartz mosaic" grains, indicative of a volcanic source, are also observed. Two different colors of glauconite are present, a light green and a yellowish-green brown. Both colors are present as rounded grains (Pl. 3, Fig. 3) indicating (1) two different periods of glauconitization and/or (2) recycled glauconite post-depositional glauconitization and/or (3) glauconitization of two different minerals. Some grains, particularly microfossils, appear to be in the early stages of glauconitization, as the shell casts of foraminifers are still visible and minor glauconite is observed along the outer rims of some radiolarians.

With the exception of the uppermost part of Core 113-693A$46 \mathrm{R}$, the biogenic component rarely exceeds $10 \%$ and decreases downhole. Fossil preservation is poor to moderate. Nannofossils and diatoms are more abundant, with trace amounts of foraminifers and radiolarians. Shell debris is also present although not as common as in Hole 692B.

Additional lithologies interbedded within this facies include thin ash (also altered to clay) layers, $0.5-3 \mathrm{~cm}$ thick, and chert. The chert layers and surrounding sediment are severely disturbed when recovered. The ash layers contain some glass shards. Under crossed nicols, most of the shards show gradual extinction, suggesting that they are recrystallized. A few, however, do not have this extinction pattern and may therefore be fresh enough to give an indication of the type of volcanism. 


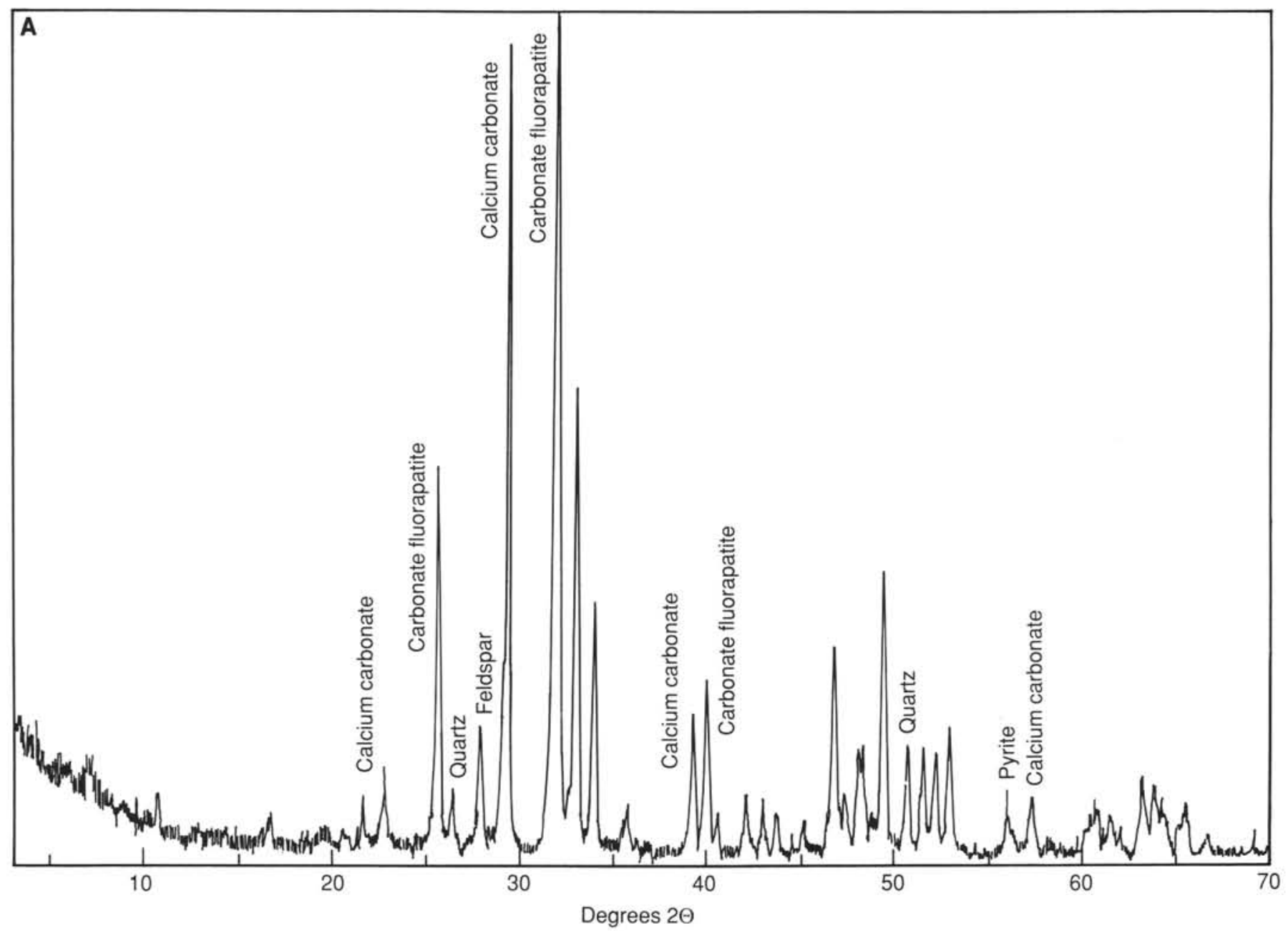

Figure 8. A. Bulk XRD analysis of Type I carbonate-clay nodule (Sample 113-692B-10R-3, 121-123 cm). B. Scan of bulk chemicals in a Type I carbonate-clay nodule with energy-dispersive SEM (Sample 113-692B-12R-3, 60-61 cm). Zn and Cu (far right) are artifacts of the analysis.

The dark color of this facies obscures sedimentary structures and makes them very difficult to see in photographs. Sedimentary structures include graded, parallel, inclined, and convolute bedding (possible slumps), scours, and bioturbation structures. The bioturbation structures increase upsection, especially above the uppermost limestone bed, where they belong to ichnofabric index 3 and 4 of Droser and Bottjer (1986) (Figs. 10 and 11). Many beds have sharp basal contacts and fine upward. Benthic foraminifers suggest relatively shallow water depths (about $500 \mathrm{~m}$ ) (Thomas, this volume) and oxygenated conditions.

Although darker in color than the Lower Cretaceous sediments at Site 692 , the organic carbon content at Site 693 is much lower, averaging $2.56 \%$, indicating more extensive pyritization. Unlike those at Site 692 , these sediments do not have hydrocarbon generation potential because of their highly oxidized condition. The low Hydrogen Index, Oxygen Index, and $\mathrm{T}_{\max }$ are unusual, and the shipboard interpretation is that this could have been generated by syndepositional oxidation of significant quantities of planktonic kerogen precursors, with an admixture of highly mature recycled kerogen (Shipboard Scientific Party, 1988).

\section{Depositional Environment}

As at Site 692, the low faunal diversity suggests low oxygen concentrations in bottom waters, again supported by the abun- dance of organic-rich sediments. However, the Lower Cretaceous section of Site 693 differs from that of Site 692 in several critical ways: lower organic carbon; common to abundant biosiliceous sediments, both as layers and nodules as well as a component in the terrigenous-dominated sediments; almost no carbonate component (Table 4) in the terrigenous-dominated sediments; limestone interbeds; thin sand layers; a lack of concretions with carbonate fluorapatite; ash layers with glass shards; and common to abundant glauconite.

Like carbonate fluorapatite, glauconite is an environmentally diagnostic mineral. It has been related to upwelling in both ancient (Debrabant and Paquet, 1975) and modern sediments (Manheim et al., 1975; Birch, 1979) and is commonly associated with phosphates, although the mode of formation of both minerals is not known. Glauconite has been reported from around $\mathrm{Eh}=0$, with different researchers favoring both slightly oxidizing and slightly reducing environments (McRae, 1972).

However, unlike carbonate fluorapatite, glauconite is also related to reduced sedimentation rates (Porrenga, 1967; Odin and Matter, 1981), and to both regressive (Porrenga, 1967; Odin and Matter, 1981) and transgressive (Hughes and Whitehead, 1987) sea-level fluctuations. The slow deposition could increase the opportunity for the oxidation of organic matter. However, the entire $75 \mathrm{~m}$ interval falls within one 9.7-m.y.-long (Haq et al., 1987) nannofossil zone (Rhagodiscus angustus, Mutterlose and 


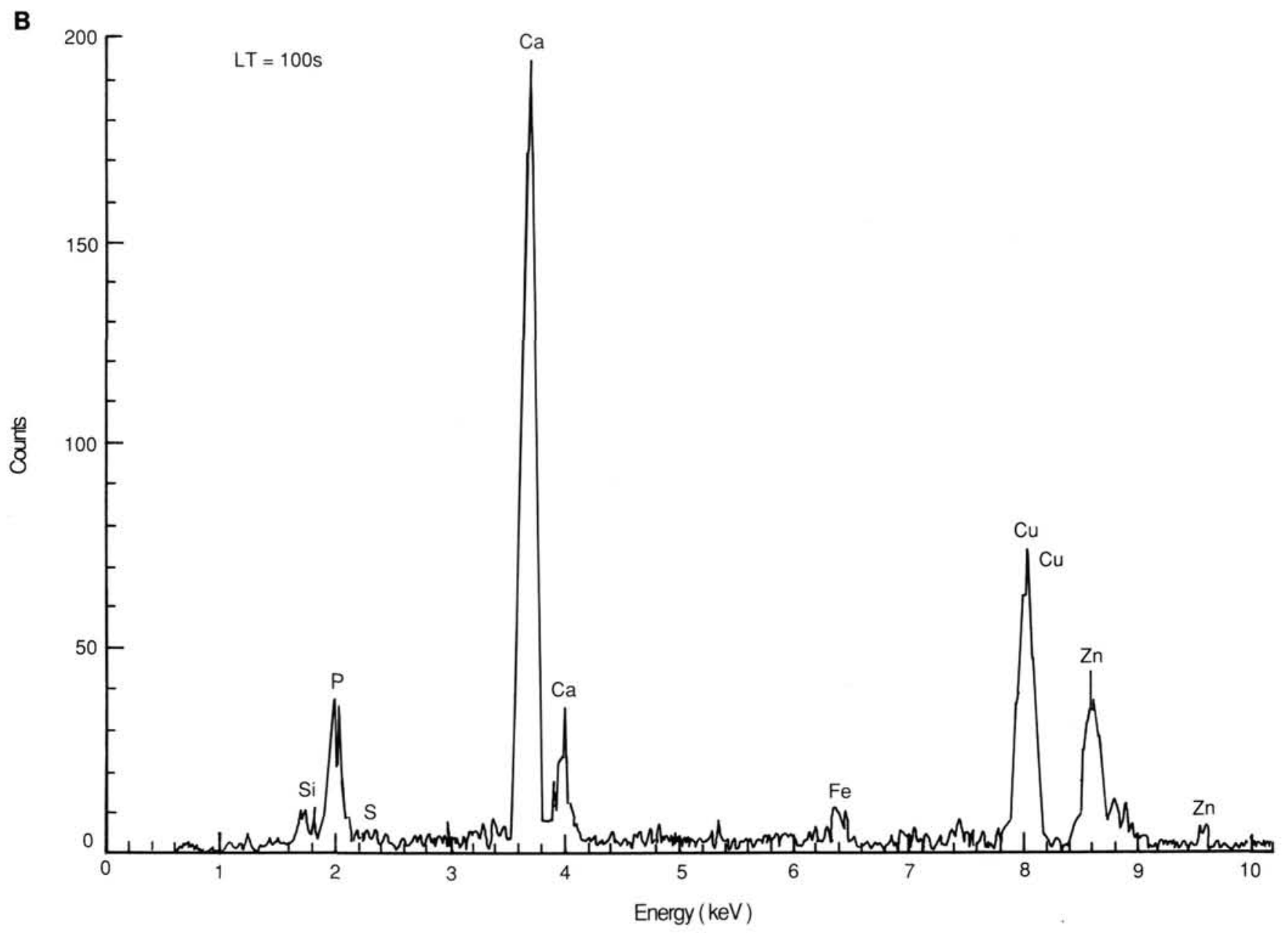

Figure 8 (continued).

Wise, this volume), indicating minimum sedimentation rates of $7.7 \mathrm{~m} / \mathrm{m}$.y. These rates are probably too high for true glauconite formation, suggesting that much of the glauconite may be recycled or that sedimentation was episodic with numerous hiatuses not resolvable by biostratigraphy. Possibly only the incipient glauconitization visible around microfossil shell casts is in situ. The age cannot be further refined by the biosiliceous material because of the poor preservation of the radiolarians (Lazarus and Ling, this volume) and the large number of new (although well-preserved) genera and species of diatoms (Gersonde and Harwood, this volume; Harwood and Gersonde, this volume).

During the 9.7 m.y. represented by the Rhagodiscus angustus Zone, five marine transgressions and four regressions are recognized on the eustatic cycle chart (Haq et al., 1987). It is likely that this area was tectonically active, as evidenced by the volcanic component and may have been isolated from the rest of the oceans by sills. Thus it is possible that water from the surrounding oceans flowed into this basin in response to tectonic activity and/or highstands. The influx of water would supply fresher water to the basin, much as in the Mediterranean at the end of the Messinian (Ryan, Hsü, et al., 1973), and may be responsible for the deposition of the three limestone beds which are present between 426.9 and 445.9 mbsf, near the top of the recovered section. The $3-\mathrm{cm}$-thick layer of limestone recovered at 474.4 mbsf occurs at the top of a core and is therefore thought to be downhole contamination. The other three limestone beds are assumed to be in situ. They may represent con- densed sections reflecting low terrigenous input and/or reworking, and be related to tectonic or eustatic sea level changes as the incipient Antarctic Ocean expanded.

In summary, during most of the late Aptian-early Albian, the Site 693 area experienced sedimentation under dysaerobic conditions, but conditions that became more oxygenated during the Albian. Although grain size is variable, there is almost no evidence for mass wasting, and sediments were dominantly finegrained, some from a volcanic source.

\section{DISCUSSION}

Five DSDP sites that were proximal to ODP Sites 692 and 693 during the Early Cretaceous (Fig. 13A and B) recovered sediments of that age (Fig. 14): Sites 249, 327, 330, 361, and 511. As at Sites 692 and 693, organic-rich sediments were recovered in variable proportions. Sites 327 and 330 were spot cored. Since they are adjacent to Site 511 , which was continuously cored, they will not be mentioned further. Sites 249 and 361 were also spot cored, but they offer the most complete sections available for their geographic locations.

Of these sites, the oldest Cretaceous sediments were recovered at Sites 249 and 692 . Site 249 , located on the present-day Mozambique Ridge in $2088 \mathrm{~m}$ of water, is the shallowest of the five sites. Total penetration was $412 \mathrm{~m}$, terminating in weathered basalt. Lithologic Unit III (287-408 mbsf), of Berriasian to early Cenomanian-late Aptian age, consists of gray, olive, and olive-black silty claystone and volcanic siltstone (Fig. 14) and is 

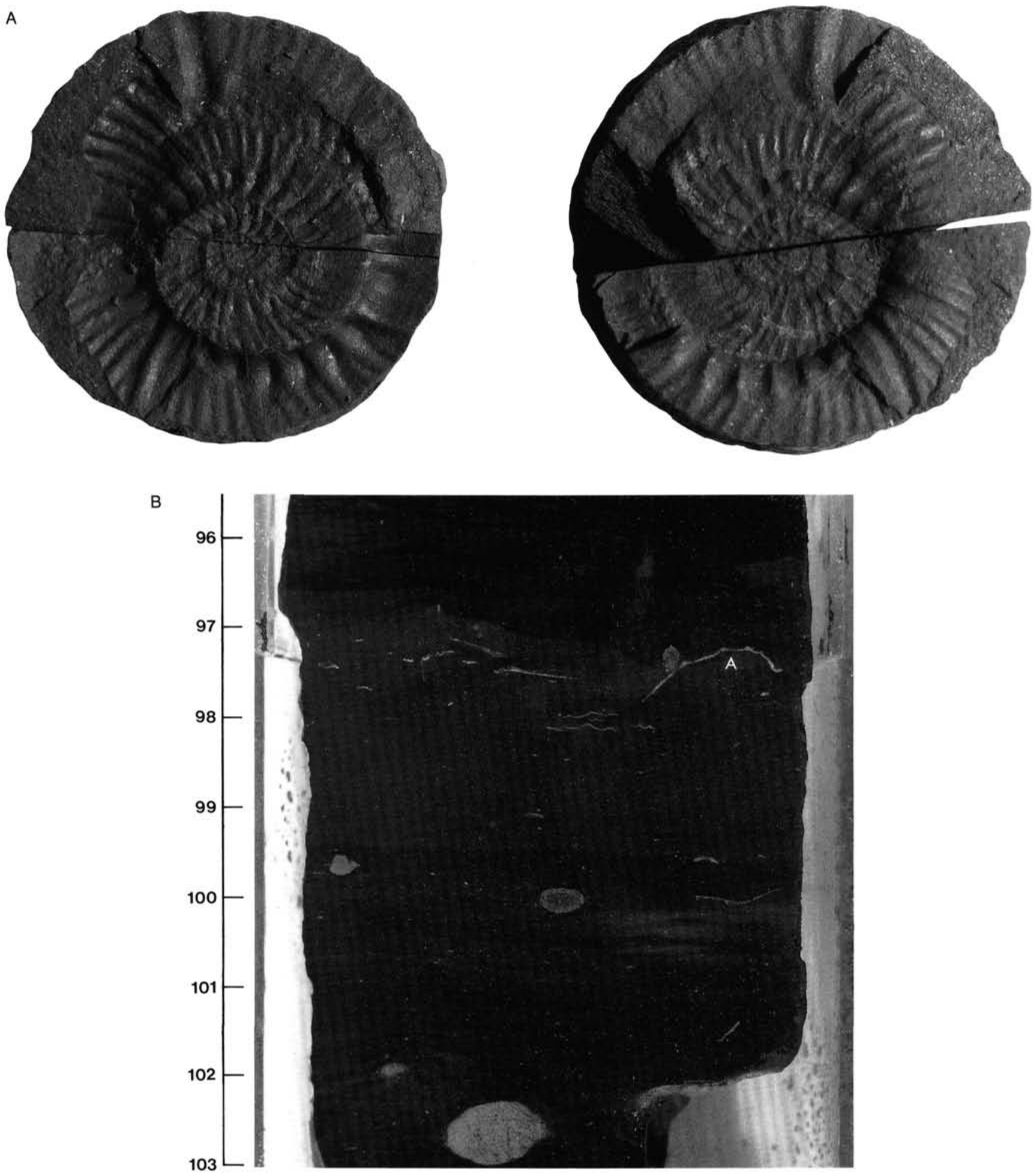

Figure 9. Macrofossils. A. Ammonite in bedding plane (Sample 113-692B-10R-2, $42 \mathrm{~cm}$ ). B. Bivalve at angle to bedding plane (A) (Interval 113-692B$12 \mathrm{R}-3,95.5-103 \mathrm{~cm}$ ).

unconformably overlain by Campanian chalk. Microfossils are sparse, making the sediments difficult to date. Organic carbon contents vary between $0 \%$ and $1.7 \%$ and average about $1 \%$. More reduced iron and higher organic carbon contents were recovered in the lower part of Unit III (subunit IIIB), of Berriasian to Hauterivian age, and thus of similar age to Unit III of Site 692 . Site 249 was most likely a small rift or pull-apart basin during the deposition of subunit IIIB. The tectonic setting of Site 692 is not as well constrained. During the Valanginian, both sites experienced dysaerobic benthic conditions and were probably isolated from each other by the abutment of the Mozambique Ridge and the Falkland Plateau. Limestone was deposited at Site $\mathbf{2 4 9}$ during the later Hauterivian and Barremian, suggesting an influx of more oxygenated water, possibly a condensed 


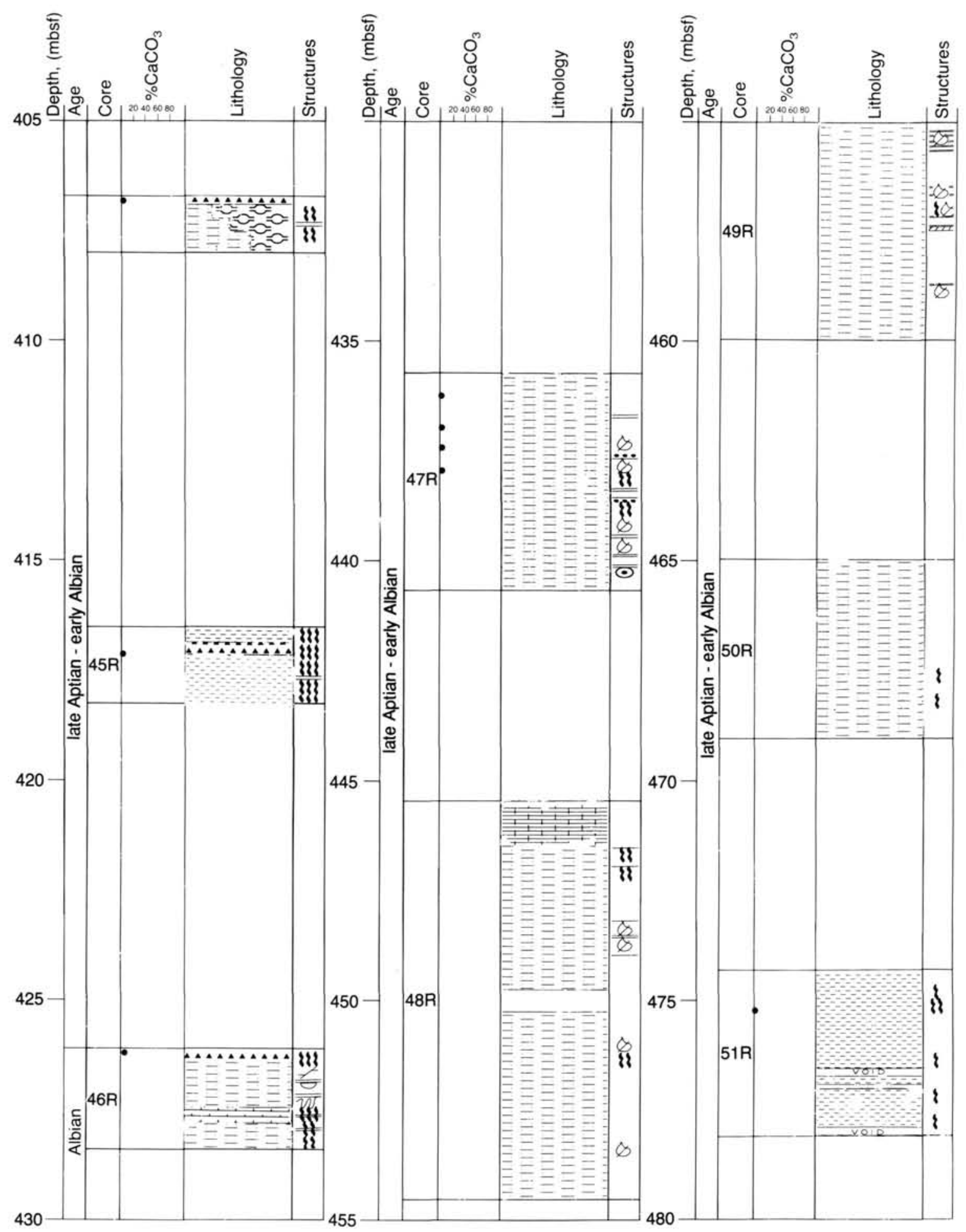

Figure 10. Generalized lithostratigraphy and sedimentary structures of Lower Cretaceous sediments from Site 693, also showing calcium carbonate content. Legend is given in Figure 2.

section, due to a relative highstand of sea level. The highstand may have been associated with the general sea level increase from the lower Valanginian to Barremian (Haq et al., 1987).

Aptian through lowermost Albian sediments were recovered at DSDP Sites 249, 361, and 511. Site 361 is located on the lower continental rise west of Cape Agulhas, South Africa, in present-day water depths of $4549 \mathrm{~m}$. The Aptian and lowermost Albian sediments recovered at this site contain abundant carbonaceous material, with percentages ranging between $0.1 \%$ and $6.1 \%$ in the sandstone and $0.4 \%$ and $14.6 \%$ in the shale. Wood fragments and cuticles form a large part of the organic material. The dominant lithologies in this unit are black to dark gray 


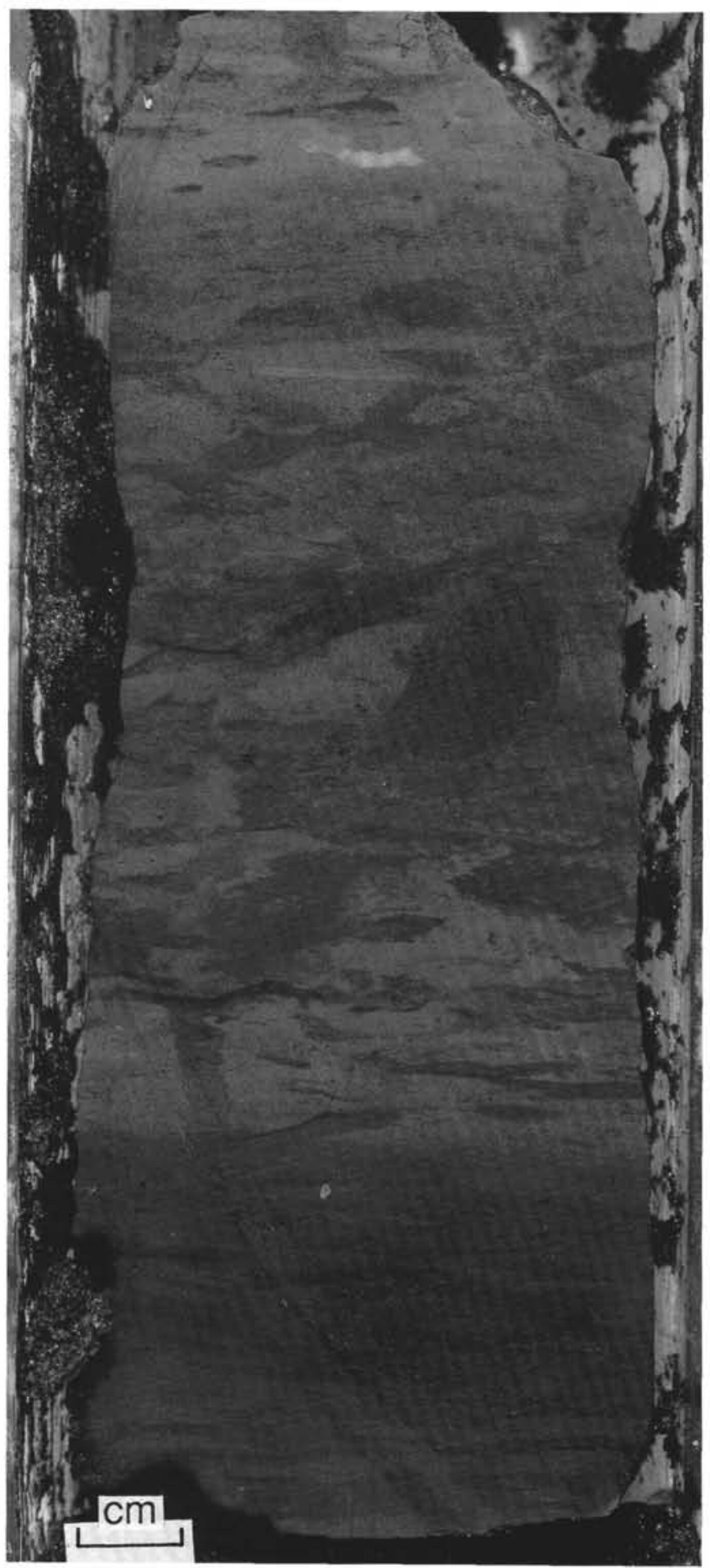

Figure 11. Bioturbation in clay-bearing radiolarian diatomite (Interval 113-693B-44R-1, 28-43 cm). The extent of bioturbation would place this interval in ichnofabric index 4 (Droser and Bottjer, 1986).

sapropelic shale and bluish-gray to greenish-gray sandy mudstone and sandstone, with minor amounts of mudstone, siltstone, and one 40 -cm-thick contorted bed of nannofossil chalk (1148 mbsf). Bedding is generally massive, with thin sandy laminae and minor graded bedding. Calcareous nannofossils are generally absent from the sandstones but are common in the shale and form a few isolated laminae. Carbonate concretions

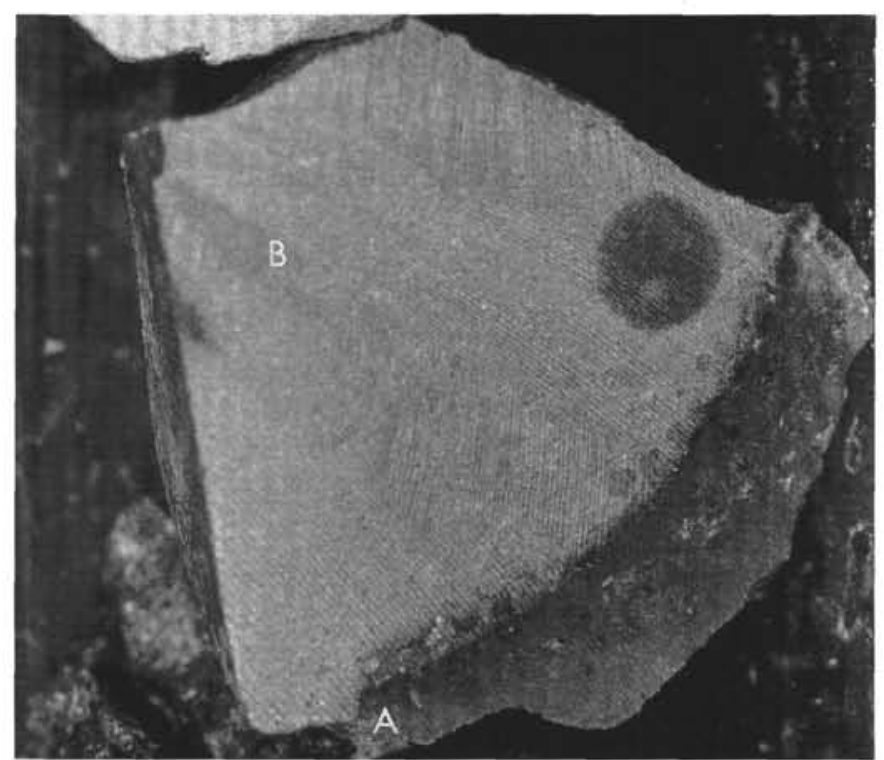

Figure 12. Pyrite rim (A) on limestone fragment (B). Dark spot is wet area. (Interval 113-693A-48R-1, 41-47 cm.)

Table 4. Calcium carbonate percentages from shipboard and shorebased analyses for Hole 693A.

\begin{tabular}{|c|c|c|}
\hline $\begin{array}{l}\text { Core, section, } \\
\text { interval }(\mathrm{cm})\end{array}$ & $\begin{array}{l}\text { Depth } \\
\text { (mbsf) }\end{array}$ & $\begin{array}{c}\mathrm{CaCO}_{3} \\
(\%)\end{array}$ \\
\hline \multicolumn{3}{|l|}{$113-693 \mathrm{~A}-$} \\
\hline $44 \mathrm{R}-1,25-27$ & 406.95 & 0.8 \\
\hline $45 \mathrm{R}-1,56-58$ & 417.06 & 0.3 \\
\hline 45R-CC, $2-5$ & 417.56 & 0.4 \\
\hline $46 \mathrm{R}-1,21-22$ & 426.31 & 5.1 \\
\hline $46 \mathrm{R}-1,82-84$ & 426.92 & 3.7 \\
\hline $46 \mathrm{R}-1,93-96$ & 427.03 & 0.8 \\
\hline $47 \mathrm{R}-1,24-25$ & 435.94 & 1.0 \\
\hline $47 \mathrm{R}-1,117-118$ & 436.87 & 2.3 \\
\hline $47 \mathrm{R}-2,30-31$ & 437.50 & 2.1 \\
\hline $47 R-2,78-80$ & 437.98 & 3.6 \\
\hline $47 \mathrm{R}-2,119-120$ & 438.39 & 3.8 \\
\hline $48 \mathrm{R}-1,24-26$ & 445.64 & 82.0 \\
\hline $48 \mathrm{R}-1,79-80$ & 446.19 & 0.5 \\
\hline $48 \mathrm{R}-1,81-83$ & 446.21 & 0.6 \\
\hline $48 \mathrm{R}-2,125-129$ & 448.15 & 1.6 \\
\hline $48 \mathrm{R}-3,83-84$ & 449.23 & 1.1 \\
\hline $48 \mathrm{R}-4,58-59$ & 450.48 & 1.3 \\
\hline $48 \mathrm{R}-4,72-74$ & 450.62 & 1.7 \\
\hline $48 R-4,104-106$ & 450.94 & 1.1 \\
\hline $49 \mathrm{R}-1,44-45$ & 455.44 & 0.8 \\
\hline $49 \mathrm{R}-2,19-21$ & 456.69 & 3.3 \\
\hline $49 \mathrm{R}-2,112-114$ & 457.62 & 5.1 \\
\hline $50 \mathrm{R}-1,40-42$ & 465.20 & 4.7 \\
\hline $50 \mathrm{R}-1,53-54$ & 465.33 & 5.3 \\
\hline 50R-1, 106-109 & 465.86 & 6.3 \\
\hline $50 \mathrm{R}-2,51-52$ & 466.81 & 2.7 \\
\hline $51 \mathrm{R}-1,40-42$ & 474.70 & 1.6 \\
\hline $51 R-1,75-79$ & 475.05 & 0.8 \\
\hline $51 \mathrm{R}-1,147-150$ & 475.77 & 0.4 \\
\hline $51 R-2,25-26$ & 476.01 & 0.6 \\
\hline $51 R-2,60-64$ & 476.36 & 1.1 \\
\hline
\end{tabular}

and pyrite laminae and concretions are present, and are especially common from Cores $361-28$ to $361-34$. The sandstones are dominantly composed of quartz $(80 \%-95 \%)$, with minor amounts of lithics (many with a silicic volcanic origin), heavy minerals, and plant debris.

At Site 511 , located in $2589 \mathrm{~m}$ of water in the present-day basin province of the Falkland Plateau (Fig. 13), Barremian through 
Table 5. Thin section descriptions and mineralogy for Hole 693A. Mineral percents are based on visual percentages (Terry and Chilingarian, 1955). Size designations are: Abundant (A) $>65 \%$, Major (M) 65\%-35\%, Common (C), 35\%-5\%, and Trace (T) $<5 \%$.

\begin{tabular}{|c|c|c|c|c|c|c|c|c|c|c|c|c|}
\hline $\begin{array}{l}\text { Core, section } \\
\text { top }(\mathrm{cm})\end{array}$ & $\begin{array}{l}\text { Depth } \\
\text { (mbsf) }\end{array}$ & 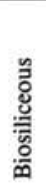 & $\begin{array}{l}\frac{n}{2} \\
\frac{0}{0} \\
\frac{\bar{\Xi}}{\text { क }}\end{array}$ & 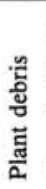 & 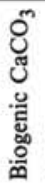 & $\frac{a}{0}$ & 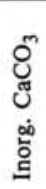 & 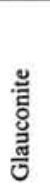 & 壱 & 䒿 & ब্] & Comments \\
\hline \multicolumn{13}{|l|}{ 113-693A- } \\
\hline $45 \mathrm{R}-1,87$ & 417.37 & C & - & $\mathrm{T}$ & - & - & - & $\mathrm{T}$ & - & $\mathrm{T}$ & M & Grain-size layering. \\
\hline $47 \mathrm{R}-1,20$ & 435.90 & $\mathrm{C}$ & $\mathbf{T}$ & $\mathrm{C}$ & - & - & $\mathrm{T}$ ? & M & $\mathrm{C}$ & $\mathrm{C}$ & C & $\begin{array}{l}\text { Glauconite sand, some biotite, } \\
\text { two colors of glauconite. }\end{array}$ \\
\hline $47 \mathrm{R}-2,44$ & 437.64 & M & - & $\mathbf{T}$ & - & - & $\mathrm{T}$ & $\mathbf{T}$ & - & C & $\mathbf{M}$ & Abundant altered silica grains. \\
\hline $48 \mathrm{R}-2,62$ & 447.52 & $\mathbf{T}$ & $\mathrm{T}$ & $\mathrm{C}$ & $\mathbf{T}$ & C & C & $\mathrm{T}$ & $\mathbf{T}$ & $\mathrm{T}$ & C & $\begin{array}{l}\text { Angular quartz, mm-scale } \\
\text { compositional grading, } \\
\text { some brown biolite. }\end{array}$ \\
\hline $48 \mathrm{R}-3,18$ & 448.58 & M & - & $\mathrm{C}$ & - & - & - & $\mathrm{T}$ & - & $\mathrm{C}$ & M & $\begin{array}{l}\text { Fine-grained, weak alignment } \\
\text { of plant debris. }\end{array}$ \\
\hline $48 \mathrm{R}-3,116$ & 449.56 & C & - & $\mathrm{C}$ & - & - & - & C & C & C & C & $\begin{array}{l}\text { Glauconitization of sponge } \\
\text { spicule. }\end{array}$ \\
\hline $49 \mathrm{R}-2,20$ & 456.70 & M & - & F & - & - & - & $\mathrm{T}$ & $\mathrm{T}$ & C & $\mathrm{C}$ & $\begin{array}{l}\text { Fine-grained radiolarite, } \\
\text { amphiboles(?), two colors } \\
\text { of glauconite. }\end{array}$ \\
\hline $50 \mathrm{R}-1,110$ & 465.90 & C & $\mathrm{T}$ & $\mathrm{C}$ & $\mathbf{T}$ & $\mathrm{C}$ & - & $\mathrm{T}$ & - & C & M & $\begin{array}{l}\text { Weak alignment, sponge } \\
\text { spicules, two colors of } \\
\text { glauconite. }\end{array}$ \\
\hline $50 \mathrm{R}-2,26$ & 466.56 & $\mathrm{~T}$ & - & C & - & $\mathrm{T}$ & $\mathbf{T}$ & C & $\mathrm{T}$ & C & $\mathrm{C}$ & $\begin{array}{l}\text { Many flattened grains, two } \\
\text { colors of glauconite, some } \\
\text { brown biotite. }\end{array}$ \\
\hline 50R-2, 71 & 467.01 & - & - & - & - & - & $\mathrm{T}$ & - & C & C & A & Ash, some fresh glass shards. \\
\hline 51R-1, 61 & 474.91 & C & - & $\mathbf{T}$ & - & - & - & - & $\mathbf{T}$ & C & M & $\begin{array}{l}\text { Radiolarite? biosiliceous } \\
\text { material very altered, one } \\
\text { color of glauconite. }\end{array}$ \\
\hline $51 R-1,118$ & 475.48 & C & $\mathbf{T}$ & C & - & - & - & - & $\mathrm{T}$ & C & $\mathbf{M}$ & $\begin{array}{l}\text { Glauconite replacing radiolari- } \\
\text { ans, radiolarian ghosts } \\
\text { common. }\end{array}$ \\
\hline
\end{tabular}

lower Aptian sediments consist of black, massive, thinly laminated mudstone and nannofossil claystone, which in places are very fissile. Below $537 \mathrm{mbsf}$ (Core 60), the mudstones are highly petroliferous and display only minor bioturbation. The mudstones are interlayered with (1) soft gray (5Y 5/1) layers $(0.5-3.0$ $\mathrm{cm}$ thick) of zeolitic claystone; (2) hard, muddy calcarenite layers; (3) less commonly, layers of concentrated pelecypod debris that form muddy microcoquinas similar to the overlying unit; and (4) layers of coarsely crystalline cone-in-cone calcite. Pyrite occurs in burrows, as finely disseminated laminae over 1-2-cmthick intervals, and as several-centimeter-thick masses. Thus, during this time sedimentation in what is the present-day South Atlantic and Weddell Sea continued to be similar to that of the older Cretaceous environments, with primarily dysaerobic conditions punctuated by anaerobic intervals.

During the remainder of the Albian, a change to more aerobic conditions was experienced at Sites 249, 511, and 693. Limestone beds became more abundant, bioturbation increased, and organic matter and iron are more oxidized. These changes can be attributed to an increase in oxygen, which may be due to changes in the tectonic setting. More oxygenated water may have entered the Weddell Basin as it opened. Site 361, however, remained dysaerobic, indicating that barriers to fresh water flow remained in the South Atlantic Basin and making the Indian Ocean a more likely source of early influx of oxygenated water.

\section{CONCLUSIONS}

The Lower Cretaceous sediments of Sites 692 and 693 were deposited in a dysaerobic environment, probably close to or within upwelling conditions. Although dysaerobic, the conditions at Site 692 were closer to anaerobic conditions, and the basin may have experienced periods of anoxia. The depositional regime changed from the Valanginian of Site 692 to the AptianAlbian of Site 693. The abundance of preserved organic material and calcium carbonate decreased, while the preservation and/or abundance of siliceous material and coarser sediments increased.

These changes can be attributed to at least four possible mechanisms: (1) a decrease in the production of organic material; (2) an increase in the oxygen level near the sediment-water interface; (3) increased bottom currents and winnowing, and (4) a change in sedimentation rates. The continuing high levels of organic matter and the presence of biosiliceous sediments support a continued upwelling regime. The presence of coarser sediments and lower organic carbon contents in the Aptian/Albian suggest either an increase in bottom current activity and/or a change in the location of the oxygen minimum zone. The increase in bioturbation suggests a change to better oxygenated conditions. This, coupled with the similar changes at the other circum-Weddell Sea sites, supports an overall increase in the ox- 

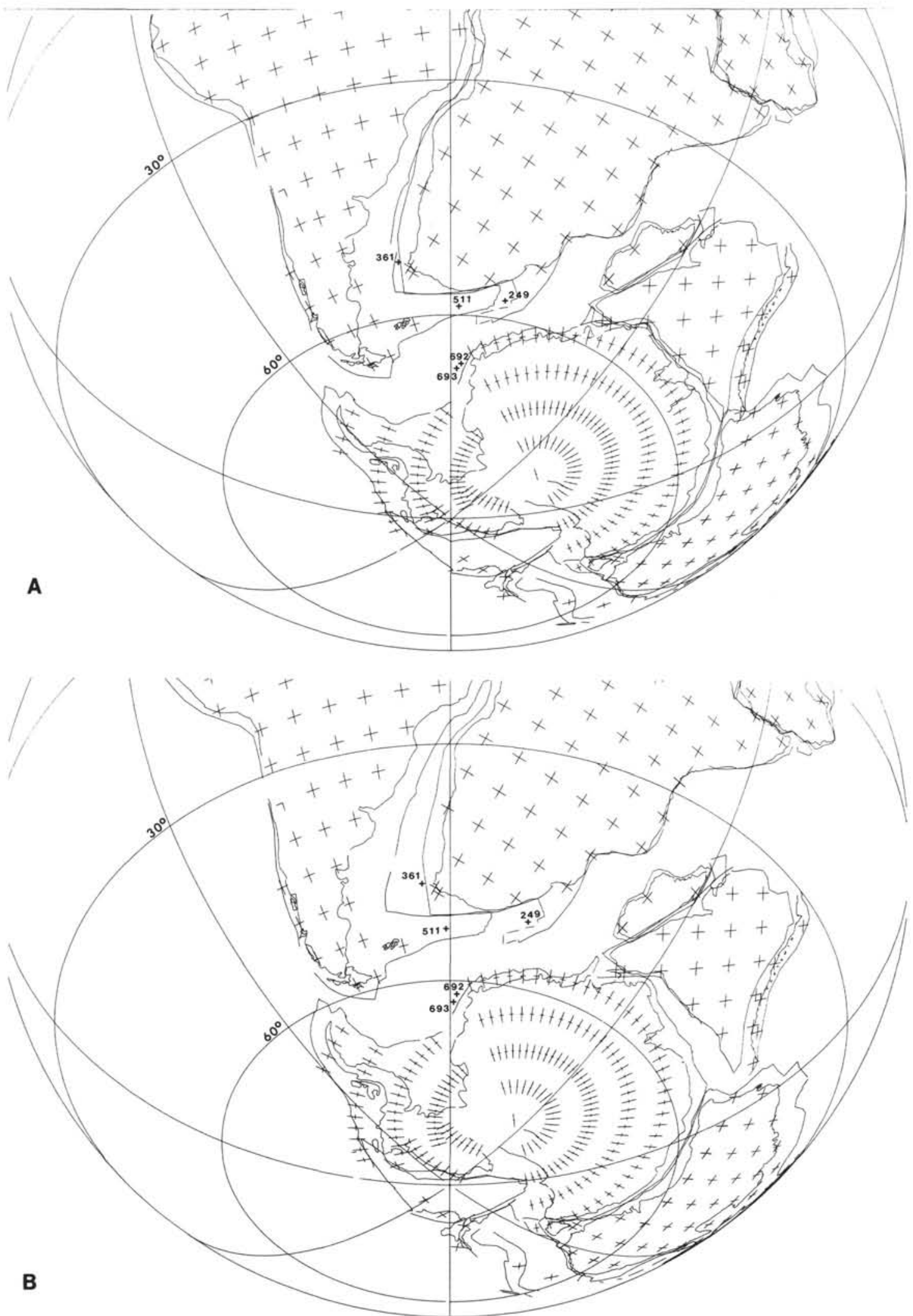

Figure 13. Southern Hemisphere, paleolatitude, plate reconstruction. Maps are plotted on orthographic projections and are reconstructed to paleolatitude based on a summation of available paleomagnetic poles from those continents whose positions are constrained independently by fitting magnetic anomalies and fracture zones (from D. Rowley, unpubl. data; Geological Society of America, Geologic time scale). A. Reconstruction for anomaly M10 (130 Ma, early Hauterivian). B. Reconstruction for anomaly M0 (118 Ma, early Aptian). 

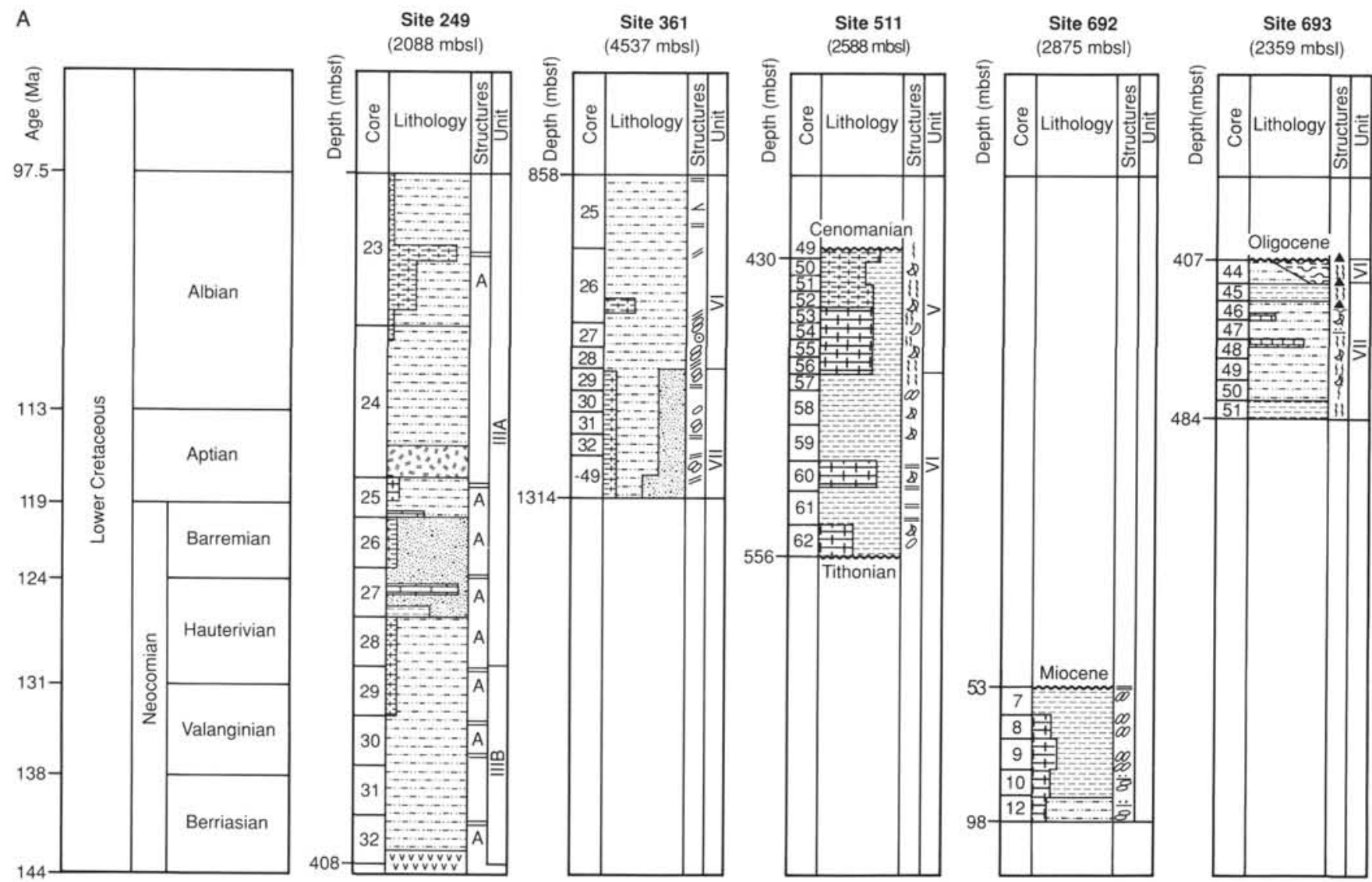

Figure 14. A. Generalized comparison of Lower Cretaceous sediments for Sites 249, 361, 511, 692, and 693. Ages are based on the Geological Society of America time scale. Legend is given in Figure 2. Although many of these sediments are organic rich, the organic component usually comprises less than $10 \%$, and commonly less than $1 \%$, of this sediment and therefore does not appear in the lithologic classification at this scale. B. Sea level curve for the Lower cretaceous (Haq et al., 1987).

ygen level at the sediment-water interface, a change which may be attributed to the initiation of South Atlantic opening.

\section{ACKNOWLEDGMENTS}

Partial funding for this study was provided by United States Advisory Committee (USSAC) grant TAMRF-5879. This paper benefited from discussions with Virgil Sharpton, Tom Tieh, Jurgen Thurow, Ulrich von Rad, and Woody Wise and reviews by T. Bralower and P. Meyer.

\section{REFERENCES}

Ames, L. L., 1959. The genesis of carbonate apatites. Econ. Geol., 54: 829-841.

Arthur, M. A., and Jenkyns, H. C., 1981. Phosphorites and paleoceanography. Oceanologica Acta., 83-96.

Banerjee, D. M., Basu, P. C., and Srivastava, N., 1980. Petrology, mineralogy and origin of the Precambrian Aravallian phosphorite deposits of Udaipur and Jhaba, India. Econ. Geol., 75:1181-1199.

Berner, R. A., 1971. Principles of Chemical Sedimentology: New York (McGraw Hill), 192-200.

Birch, G. F., 1979. The association of glauconite and apatite minerals in phosphatic rocks from the South African margin. Trans. Geol. Soc. South Africa, 82:43-53.

Bolli, H. M., Ryan, W.B.F., et. al., 1978. Init. Repts. DSDP, 40: Washington (U.S. Govt. Printing Office).

Burnett, W. C., 1980. Apatite-glauconite associations off Peru and Chile: palaeo-oceanographic implications. J. Geol. Soc. London, 137:757-764.
Debrabant, P., and Paquet, J., 1975. L'association glauconites-phosphates-carbonates (Albien de la Sierra de Espuna, Espagne meridionale). Chem. Geol., 15:61-75.

Diester-Haass, L., 1978. Sediments as indicators of upwelling. In Boje, R., and Tomczak, M. (Eds.), Upwelling Ecosystems: Berlin (SpringerVerlag), 261-281.

Droser, M. L., and Bottjer, D. J., 1986. A semiquantitative field classification of ichnofabric. J. Sediment. Petrol., 54:558-560.

Dunbar, R. B., 1983. Stable isotope record of upwelling and climate from Santa Barbara Basin, California. In Thiede, J., and Suess, E. (Eds.), Coastal Upwelling, Its Sediment Record: Part B: Sedimentary Records of Ancient Coastal Upwelling. New York (Plenum Press), 217-246.

Flexer, A., 1971. Late Cretaceous palaeogeography of northern Israel and its significance for the Levant geology. Palaeogeogr., Palaeoclimatol., Palaeoecol., 10:293-316.

Garrels, R. M., and Christ, C. L., 1965. Solutions, Minerals, and Equilibria: New York (Harper and Row).

Haq, B. U., Hardenbol, J., and Vail, P. R., 1987. Chronology of fluctuating sea levels since the Triassic. Science, 235:1156-1167.

Huffman, E.W.D., 1977. Performance of a new automated carbon dioxide coulometer. Microchem. J., 22:567-573.

Hughes, A. D., and Whitehead, D., 1987. Glauconitization of detrital silica substrates in the Barton Formation (upper Eocene) of the Hampshire Basin, southern England. Sedimentology, 34:825-835.

Kazakov, A. V., 1937. The phosphorite facies and the genesis of phosphorites. In Russian Sci. Inst. Fert. Insecto-Fungicides, Geological Investigations of Agricultural Ores Transactions: Leningrad (Inter. Geol. Congress), 142:95-113. 


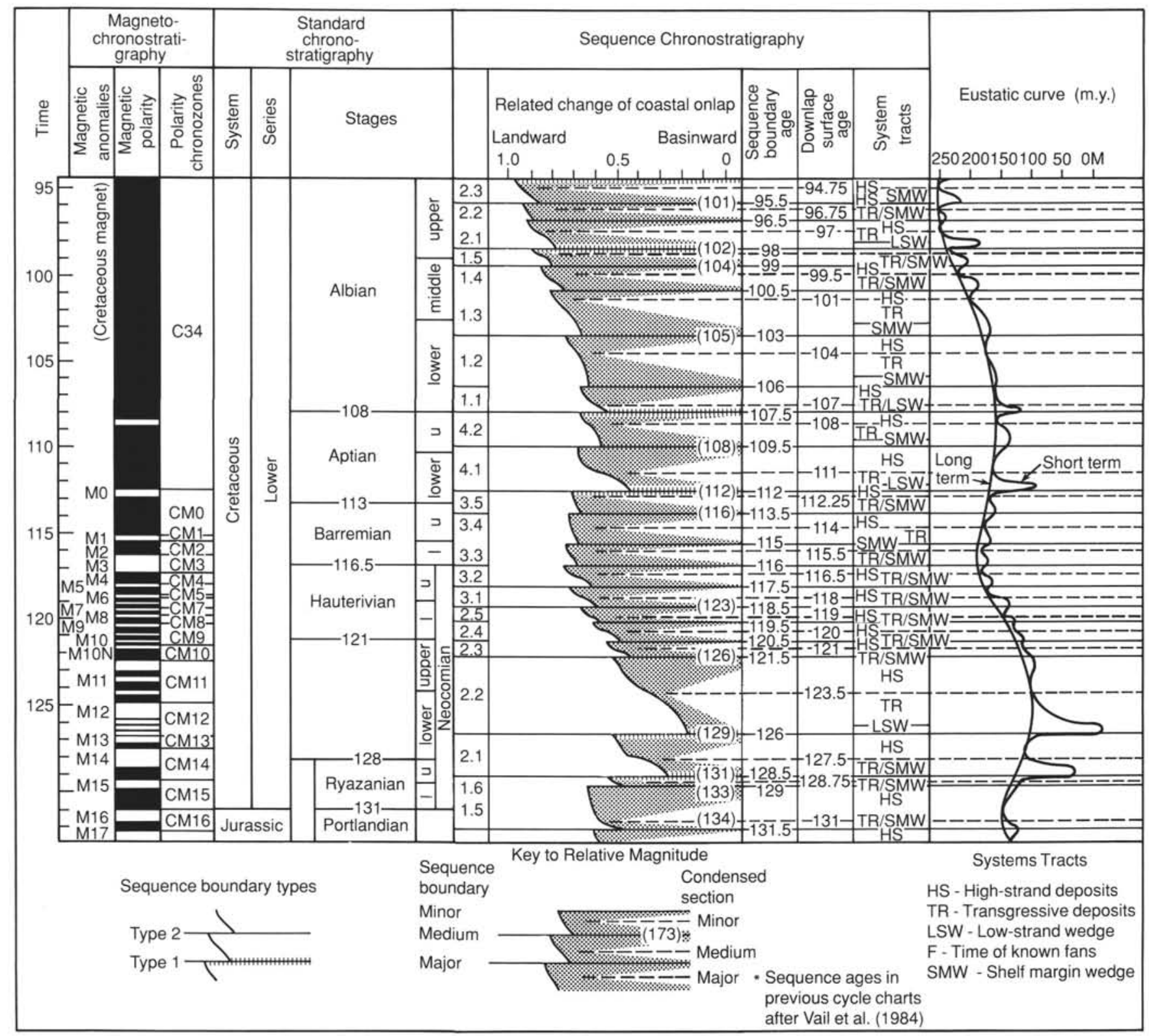

Figure 14 (continued).

Kemper, E., and Zimmerle, W., 1983. Facies patterns of a Cretaceous/ Tertiary subtropical upwelling system (Great Syrian Desert) and an Aptian/Albian boreal upwelling system (NW Germany). In Thiede, J., and Suess, E. (Eds.), Coastal Upwelling, Its Sediment Record: Part B: Sedimentary Records of Ancient Coastal Upwelling. New York (Plenum Press), 501-533.

Krissek, L. A., and Scheidegger, K. F., 1983. Environmental controls on sediment texture and composition in low oxygen zones off Peru and Oregon. In Thiede, J., and Suess, E. (Eds.), Coastal Upwelling, Its Sediment Record: Part B: Sedimentary Records of Ancient Coastal Upwelling. New York (Plenum Press), 163-180.

Manheim, F., Rowe, G. T., and Jipa, D., 1975. Maine phosphorite formation off Peru. J. Sediment. Petrol., 45: 235-251.

Martens, C. S., and Harriss, R. C., 1970. Inhibition of apatite precipitation in the marine environment by magnesium ions. Geochim. Cosmochim. Acta, 34:621-625.

McKelvey, V. E., 1967. Phosphate deposits. U.S. Geol. Surv. Bull. 1252D: D1-D2.

McRae, S. G., 1972. Glauconite. Earth Science Reviews, 8:397-440.

Meyers, P. A., and Mitterer, R. M., 1986. Introduction and overview. In Meyers, P. A., and Mitterer, R. M. (Eds.), Deep Ocean Black Shales:
Organic Geochemistry and Paleoceanographic Settings, Mar. Geol., Special Issue, 70:1-8.

Monteiro, J. H., Abrantes, F. G., Alveirinho-Dias, J. M., and Gasper, L. C., 1983. Upwelling records in recent sediments from southern Portugal: a reconnaissance survey. In Thiede, J., and Suess, E. (Eds.), Coastal Upwelling, Its Sediment Record: Part B: Sedimentary Records of Ancient Coastal Upwelling. New York (Plenum Press), 145-162.

O'Brien, G. W., and Veeh, H. H., 1983. Are phosphorites reliable indicators of upwelling? In Thiede, J., and Suess, E., (Eds.), Coastal Upwelling, Its Sedimentary Record, Part A. New York (Plenum Press), 399-420.

Odin, G. S., and Matter, A., 1981. De glauconiarum origine. Sedimentology, 28:611-641.

Pevear, D. R., 1966. The estuarine formation of the United States Atlantic Coastal Plain phosphorites. Econ. Geol., 61:251-256.

Porrenga, D. H., 1967. Glauconite and chamosite as depth indicators in the marine environment. Mar. Geol., 5:495-501.

Reimers, C. E., and Suess, E., 1983. Spatial and temporal patterns of organic matter accumulation on the Peru continental margin. In Thiede, J., and Suess, E. (Eds.), Coastal Upwelling, Its Sediment 


\section{S. B. O'CONNELL}

Record: Part B: Sedimentary Records of Ancient Coastal Upwelling. New York (Plenum Press), 311-345.

Ryan, W.B.F., Hsü, K. J., et al., 1973. Init. Repts. DSDP, 40: Washington (U.S. Govt. Printing Office).

Savdra, C. E., Bottjer, D. J., and Gorsline, D. S., 1984. Development of a comprehensive oxygen-deficient marine biofacies model: evidence from Santa Monica, San Pedro, and Santa Barbara Basins, California continental borderland. Am. Assoc. Petrol. Geol., 68: 1179-1192.

Schrader, H. J., and Schuette, G., 1981. Marine diatoms. In Emiliani, C. (Ed.), The Sea: The Oceanic Lithosphere, New York (Wiley and Sons), 7:1178-1232.

Shipboard Scientific Party, 1988. Sites 691-693. In Barker, P. F., Kennett, J. P., et al., Proc. ODP, Init. Repts., 113: College Station, TX (Ocean Drilling Program).

Simpson, E.S.W., Schlich, R., et al., 1974, Init. Repts. DSDP, 34: Washington (U.S. Govt. Printing Office).
Terry, R. D., and Chilingarian, G. V., 1955. Summary of "Concerning some additional aids in studying sedimentary formations" by M. S. Shetsov. J. Sediment. Petrol., 25:2229-2234.

Van Moort, J. C., 1973. The magnesium and calcium contents of sediments, especially pelites, as a function of age and degree of metamorphism. Chem. Geol., 12:1-37.

von Rad, U., and Botz, R., 1983. Authigenic Fe-Mn carbonates in Cretaceous and Tertiary sediments of the continental rise off eastern North America, DSDP Site 603. In van Hinte, J. E., and Wise, S. W., Jr., et al., Init. Repts. DSDP , 93: Washington (U.S. Govt. Printing Office), 1061-1077.

Wada, H., and Okada, H., 1983. Nature and origin of deep-sea carbonate nodules collected from the Japan Trench. In Watkins, J. S., and Drake, C. L. (Eds.), Studies in Continental Margin Geology. Am. Assoc. Pet. Geol. Mem., 34:661-672.

Date of initial receipt: 5 July 1989

Date of acceptance: 20 November 1989

Ms 113B-150 